\title{
USE OF PARTIALLY HYDROLYZED PVA FOR BORON CARBIDE SYNTHESIS FROM POLYMERIC PRECURSOR
}

\author{
OGUZ KARAAHMET, ${ }^{\text {B BUGRA CICEK }}$ \\ Ylldiz Technical University, Department of Metallurgical and Materials Engineering, \\ 34210, Esenler, Istanbul, Turkey \\ \#E-mail: bugracicek@gmail.com
}

Submitted April 24, 2020; accepted June 8, 2020

\begin{abstract}
Keywords: Industrial raw materials, Sol-gel, $\mathrm{pH}$, Composition ratio, Single-source reactant, Low temperature, Boron Carbide $\left(\mathrm{B}_{4} \mathrm{C}\right)$, Hydrolyzed PVA
\end{abstract}

\begin{abstract}
Boron carbide $\left(B_{4} C\right)$ synthesis from a polymeric precursor is an alternative to a traditional carbothermal reduction, promising low energy consumption and production costs, particularly for a polymeric precursor such as polyvinyl borate (PVBO). The sol-gel technique is preferred in the production of polymeric precursors owing to its convenience in producing singlesource reactants for synthesizing $B_{4} C$ at low temperatures $\left(<1800{ }^{\circ} \mathrm{C}\right)$. The sol-gel parameters, such as the composition, viscosity, and $\mathrm{pH}$, affect the formation of the polymeric precursor. In this study, industrial-grade partially hydrolyzed $P V A$ and technical-grade boric acid $\left(\mathrm{H}_{3} \mathrm{BO}_{3}\right)$ are used to produce $P V B O$. We aim to specify the viscosity and $\mathrm{pH}$ values for different ratios of $\mathrm{PVA}: \mathrm{H}_{3} \mathrm{BO}_{3}$. A sample with a weight ratio of PVA:H3BO3 of 1:1 (PHD101) is determined to have the optimum process parameters. Calcination is performed between $500{ }^{\circ} \mathrm{C}$ and $700{ }^{\circ} \mathrm{C}$ for $1-3 \mathrm{~h}$ to produce a single-source reactant, which consists of boron oxide $\left(\mathrm{B}_{2} \mathrm{O}_{3}\right)$ and carbon. It was observed that $\mathrm{B}_{2} \mathrm{O}_{3}$ was distributed on the nano-scale level in the carbon matrix. The reactant is heat-treated at $1400^{\circ} \mathrm{C}$ for $5 \mathrm{~h}$ and crystalline, polyhedral, and irregular B4C particles are synthesized at low temperatures from industrial grade raw materials.
\end{abstract}

\section{INTRODUCTION}

Boron carbide $\left(\mathrm{B}_{4} \mathrm{C}\right)$ is among the most preferred ceramic materials for defense, abrasion, and nuclear applications. It is a highly effective armor material owing to its engineering properties, such as hardness $(\mathrm{HV}=29.1 \mathrm{GPa})$, density $\left(\mathrm{d}=2.52 \mathrm{~g} \cdot \mathrm{cm}^{-3}\right)$, and abrasion resistance [1-3]. Specifically, it is the one of the hardest materials, and it is the hardest material at temperatures exceeding $1100{ }^{\circ} \mathrm{C}$. The nuclear absorption capability of the ${ }^{10} \mathrm{~B}$ isotope (at a cross section of $400-750 \mathrm{~b}$ ) has led to the use of $\mathrm{B}_{4} \mathrm{C}$ in control rods, neutron shields, and detectors in nuclear reactors [1-7]. Furthermore, $\mathrm{B}_{4} \mathrm{C}$ is a chemically inert material and has an acceptable oxidation resistance below $1000{ }^{\circ} \mathrm{C}$, enabling its use as a coating material $[2,5,8,9]$. However, it has inferior fracture toughness $(3.7 \mathrm{MPa} \cdot \sqrt{\mathrm{m}})$ [10]. On the other hand, its lower diffusion coefficient and strong covalent bonding structure limits the sinterability of $\mathrm{B}_{4} \mathrm{C}$ [11-13]. Therefore, it is crucial to densify the $\mathrm{B}_{4} \mathrm{C}$ powder at elevated sintering temperatures $\left(>2000{ }^{\circ} \mathrm{C}\right)$ using a hotpress and pressureless sintering to achieve the maximum theoretical density and superior mechanical properties of the resulting $\mathrm{B}_{4} \mathrm{C}$ ceramics $[2,4,14]$.

Boron carbide can be synthesized using existing methods, including a carbothermal reduction, magnesiothermic reduction, chemical vapor deposition, synthesis from elements, solvothermal reductions, and synthesis from polymeric precursors [2, 4, 15-23]. A conventional carbothermal reduction method is commonly used in commercial electric arc-furnace systems [24]. However, this method is extremely expensive and ineffective for the production of $\mathrm{B}_{4} \mathrm{C}$ owing to its high production temperature $\left(>2000{ }^{\circ} \mathrm{C}\right)$, difficult-to-control stoichiometry, free remaining carbon, necessary finishing processes (such as grinding and leaching to resolve contamination), and long processing time [2, 4, 23-25, 26]. Other synthesis methods, such as a magnesiothermic reduction and chemical vapor deposition, are not costeffective at an industrial scale. For these reasons, $\mathrm{B}_{4} \mathrm{C}$ synthesis using a polymeric precursor has emerged as an alternative method to a carbothermal reduction because a polymer has a convenient controlled composition ratio for use in ceramics, a facile formation, and decomposed at low temperature [22]. Both synthesis methods can use similar boron sources, such as boric acid $\left(\mathrm{H}_{3} \mathrm{BO}_{3}\right)$ and boron oxide $\left(\mathrm{B}_{2} \mathrm{O}_{3}\right)$. However, the carbon sources differ from those used in the carbothermal method. Boron carbide synthesis with a polymeric precursor uses polyol materials, such as polyvinyl alcohol (PVA), citric acid, glycerol, phenolic resin, and saccharides [22, 27-31]. These chemicals are organic compounds in which the $\mathrm{C}-\mathrm{O}-\mathrm{H}$ bonds have a branched chemical structure. The boron and carbon sources are mixed homogeneously 
through a dehydration-condensation reaction from the polyol materials and $\mathrm{H}_{3} \mathrm{BO}_{3}$, and the surface area of the reactants is increased [32-36]. In addition, $\mathrm{B}-\mathrm{O}-\mathrm{C}$ borate ester bonds in a cross-linking structure are achieved during the dehydration-condensation reaction and yield polyvinyl borate (PVBO) as a polymeric precursor. Pyrolysis or calcination is then applied within the range of $400{ }^{\circ} \mathrm{C}$ to $800{ }^{\circ} \mathrm{C}$. Borate ester bonds are destroyed through heat treatment and form a structure with $\mathrm{B}_{2} \mathrm{O}_{3}$ distributed in the $\mathrm{C}$ matrix [28]. Thus, a single-source raw material or reactant can be used to synthesize $\mathrm{B}_{4} \mathrm{C}$ at low temperatures $\left(<1800^{\circ} \mathrm{C}\right)$. The aim of the precursor synthesis from polymeric materials and boron resources is to mix the reactants at molecular levels. A homogenous and uniform reactant distribution during $\mathrm{B}_{4} \mathrm{C}$ synthesis leads to an extended intersurface contact between boron and carbon atoms [37], shortening the necessary diffusion route and decreasing the energy of diffusion activation, thereby facilitating the diffusion among the atoms [28]. The structure obtained during the pyrolysis step decreases the thermodynamically and kinetically necessary $\mathrm{B}_{4} \mathrm{C}$ synthesis temperatures above $2000{ }^{\circ} \mathrm{C}$ and reduces the reaction time [28, 38]. By contrast, residual free carbon in the structure of $\mathrm{B}_{4} \mathrm{C}$ materials is the main problem for polymeric precursor synthesis methods [34]. This problem can be solved by optimizing the PVA: $\mathrm{H}_{3} \mathrm{BO}_{3}$ and $\mathrm{C}: \mathrm{B}_{2} \mathrm{O}_{3}$ ratios and applying thermal decomposition in air [27, 31, 34, 35, 38].

The sol-gel method was used to synthesize the polymeric precursor and determine the physical properties of the end products formed through the following processing. The sol-gel process parameters were affected by the properties of the raw materials, structure of the reactant, and properties of the $\mathrm{B}_{4} \mathrm{C}$. Sol-gel parameters, such as the solubility, viscosity, and $\mathrm{pH}$, vary with the molecular weight, degree of polymerization, and degree of hydrolysis of the PVA, as well as the concentration ratio of the raw materials. Few data are available in the literature regarding the sol-gel process parameters and the effect of the properties of the raw materials applied. In general, the effect of the concentration ratio has been investigated from the composition of the fully hydrolyzed PVA, and the crystalline $\mathrm{B}_{4} \mathrm{C}$ powder synthesized at low temperature $\left(1200-1500^{\circ} \mathrm{C}\right)[27,28,38]$. The viscosity of the PVA-water and $\mathrm{H}_{3} \mathrm{BO}_{3}$-water solutions was affected by the polymeric precursor's structure. The water evaporates due to the temperature, and thus the viscosity of the solution increases. Lower viscosity could allow an improved dispersion of boron and carbon in the solution. Thus, the gel was collected a few times to obtain a lower viscosity [37]. However, no detailed information regarding this is yet available in the literature so far. The $\mathrm{pH}$ is critical to the particle size and solution during the sol-gel processes [39]. If the $\mathrm{pH}$ of the solution is less than 5 , the viscosity can decrease and the activation between particles can increase. Conversely, if the $\mathrm{pH}$ of the solution increases, the viscosity decreases and a homogeneous solution cannot be obtained [35, 39]. Highly hydrolyzed PVA has been used in previous studies, although few articles have been published regarding $\mathrm{B}_{4} \mathrm{C}$ synthesis from partially hydrolyzed $\mathrm{PVA}-\mathrm{H}_{3} \mathrm{BO}_{3}$ [29]. In this study, we used partially hydrolyzed (88 \%) and low-molecular-weight (19000-24015) PVA and technical-grade $\mathrm{H}_{3} \mathrm{BO}_{3}$ as the raw materials to synthesize $\mathrm{PVBO}$ and to investigate the effect of the initial concentration ratio on the solution viscosity and $\mathrm{pH}$. As a result, $\mathrm{B}_{4} \mathrm{C}$ could be synthesized from the PVBO.

\section{EXPERIMENTAL}

\section{Materials}

The materials used were boric acid $\left(\mathrm{H}_{3} \mathrm{BO}_{3}\right.$, $99.92 \%,<450 \mu \mathrm{m}$ ), polyvinyl alcohol (PVA, degree of hydrolysis of $88, \leq 5.0 \%$ volatile contents, $<800 \mu \mathrm{m}$ ), and distilled water. Raw materials were used as the starting compounds.

\section{Synthesis of PVBO materials}

The synthesis of PVBO was achieved using a dehydration-condensation reaction of PVA and $\mathrm{H}_{3} \mathrm{BO}_{3}$. First, PVA (1.0 - $3.1 \mathrm{~g})$ was dissolved in distilled water $(60 \mathrm{ml})$ at $80^{\circ} \mathrm{C}$ for $0,20,40$, and 60 min under continuous stirring using a magnetic stirrer. At the same time, $\mathrm{H}_{3} \mathrm{BO}_{3}$ $(0.645-2.0 \mathrm{~g})$ was dissolved in distilled water $(30-45 \mathrm{ml}$, according to the amount $\mathrm{H}_{3} \mathrm{BO}_{3}$ ) (Table 1$)$ at $60{ }^{\circ} \mathrm{C}$ for 0 - 60 min under continuous stirring by a magnetic stirrer. The $\mathrm{H}_{3} \mathrm{BO}_{3}$ solution was then slowly added to the PVA solution at $80{ }^{\circ} \mathrm{C}$ under continuous stirring for approximately $5 \mathrm{~min}$. The composition ratio of PVA/ $/ \mathrm{H}_{3} \mathrm{BO}_{3}$ and amounts of PVA and $\mathrm{H}_{3} \mathrm{BO}_{3}$ are listed in Table 2. The PVBO white gel agglomerated on the surface of the reaction mixture $5 \mathrm{~min}$ and $60 \mathrm{~min}$ after the gel was collected, or the process was continued until the water in the condensation solution evaporated. The synthesis of $\mathrm{PVBO}$ was completed at $80^{\circ} \mathrm{C}$ under constant stirring. The white gel of PVBO or its precursor was dried at $120{ }^{\circ} \mathrm{C}$ for $24 \mathrm{~h}$ in an oven (Elektro-mag, M5040P) and ground by an agate mortar (Retsch Planetary Ball Mill-PM100). After the precursor powder was screened under $250 \mu \mathrm{m}$, it was charged in a porcelain crucible. Further, the samples were calcinated at 500, 600, and $700{ }^{\circ} \mathrm{C}$ for 1,2 , and $3 \mathrm{~h}$ in air by using a chamber furnace (Protherm, PLF 140/5). The samples were ground using an agate mortar and uniaxially compacted with a cold press. The sample was then placed in an alumina boat and heat treated for $\mathrm{B}_{4} \mathrm{C}$ reduction in a tube furnace at $1400{ }^{\circ} \mathrm{C}$ under Ar flow $\left(800 \mathrm{ml} \cdot \mathrm{min}^{-1}\right)$ for $5 \mathrm{~h}$ at a heating rate of $8{ }^{\circ} \mathrm{C} \cdot \mathrm{min}^{-1}$. After the reduction was completed, the sample was cooled to room temperature under an $\mathrm{Ar}$ flow $\left.800 \mathrm{ml} \cdot \mathrm{min}^{-1}\right)$. The full experimental procedure is shown in Figure 1. 
Table 1. Amount of $\mathrm{H}_{3} \mathrm{BO}_{3}$ and composition ratio of $\mathrm{H}_{3} \mathrm{BO}_{3}: \mathrm{H}_{2} \mathrm{O}$

\begin{tabular}{llr}
\hline Code & $\mathrm{H}_{3} \mathrm{BO}_{3}(\mathrm{~g})$ & $\mathrm{H}_{3} \mathrm{BO}_{3}(\mathrm{~g}): \mathrm{H}_{2} \mathrm{O}(\mathrm{ml})$ \\
\hline HW101 & 2.0 & $2: 45$ \\
HW151 & 1.33 & $1.33: 45$ \\
HW201 & 1.0 & $1: 30$ \\
HW251 & 0.8 & $0.8: 30$ \\
HW311 & 0.645 & $0.645: 30$ \\
\hline
\end{tabular}

Table 2. Composition ratio of $\mathrm{PVA} / \mathrm{H}_{3} \mathrm{BO}_{3}$ and amounts of PVA and $\mathrm{H}_{3} \mathrm{BO}_{3}$.

\begin{tabular}{lccc}
\hline Code & $\mathrm{PVA}_{3} \mathrm{H}_{3} \mathrm{BO}_{3}$ ratio & $\mathrm{PVA}(\mathrm{g})$ & $\mathrm{H}_{3} \mathrm{BO}_{3}(\mathrm{~g})$ \\
\hline PHD101 & $1.0: 1$ & 2.0 & 2.0 \\
PHD151 & $1.5: 1$ & 2.0 & 1.33 \\
PHD201 & $2.0: 1$ & 2.0 & 1.0 \\
PHD251 & $2.5: 1$ & 2.0 & 0.8 \\
PHD311 & $3.1: 1$ & 2.0 & 0.645 \\
\hline
\end{tabular}

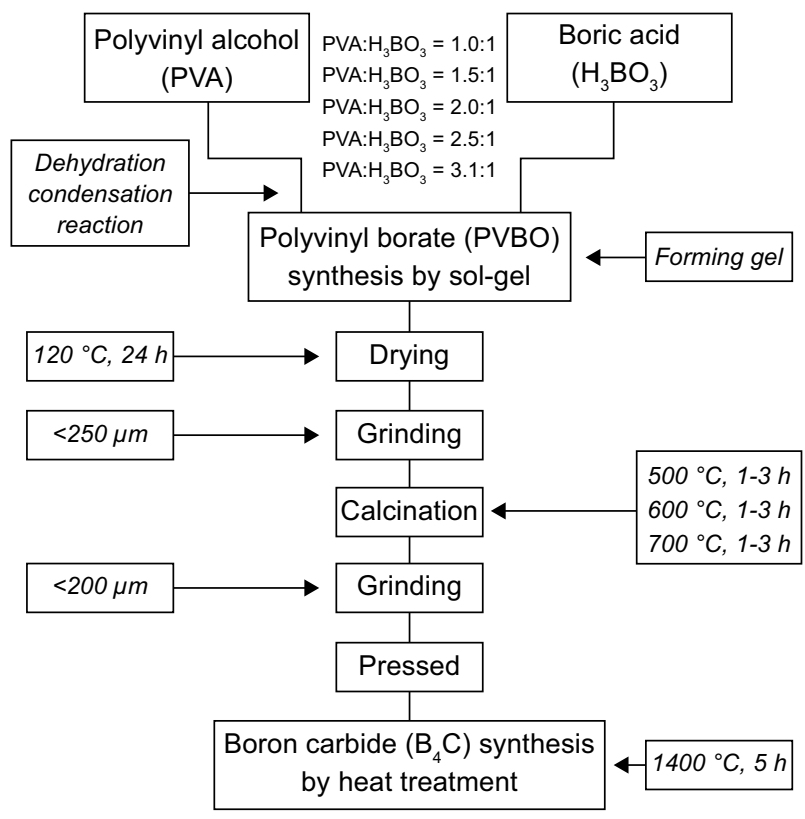

Figure $1 . \mathrm{B}_{4} \mathrm{C}$ synthesis procedure.

\section{Characterization}

The PVA-water solution concentration $\left(P W C_{A R}\right)$ was determined according to the formula presented below.

$$
P W C_{A R}=\frac{\left[P_{S W}-\left(P_{S W} \times 5 / 100\right)\right]}{P D W_{W}-P_{R W}} \times 100,
$$

where $P_{S W}$ is the initial weight of PVA, $P_{R W}$ is the PVA remaining after removing the weight of the volatiles in the PVA (5\%, according to technical data sheet of the product), and $P W_{W}$ is the weight of the PVA-water solution after heating.

The concentration of the $\mathrm{H}_{3} \mathrm{BO}_{3}$-water solution $\left(H W C_{A R}\right)$ was determined according to the following formula:

$$
H W C_{A R}=\frac{H_{S W}}{H W_{W}-H_{S W}} \times 100,
$$

where $H_{S W}$ is the initial weight of $\mathrm{H}_{3} \mathrm{BO}_{3}$ and $H W_{W}$ is the amount of the $\mathrm{H}_{3} \mathrm{BO}_{3}$-water solution after the preparation. In addition, $\mathrm{H}_{3} \mathrm{BO}_{3}$ was dissolved in water and the structure was protected such that the $\mathrm{H}_{3} \mathrm{BO}_{3}$ dissolved in the water would remain at similar amounts. The $\mathrm{C} / \mathrm{B}_{2} \mathrm{O}_{3}$ mole ratio $\left(\mathrm{CB}_{M}\right)$ of the reactant after calcination was calculated using the solubility of $\mathrm{B}_{2} \mathrm{O}_{3}$ in water. First, the reactant was charged in distilled water and continuously stirred at $80{ }^{\circ} \mathrm{C}$ for $20 \mathrm{~min}$. Carbon and $\mathrm{B}_{2} \mathrm{O}_{3}$ were able to separate from each other in water. The reactant-water mixture was filtrated, leaving carbon particles in the filter. The filter and carbon particles were then dried at $80{ }^{\circ} \mathrm{C}$ for $30 \mathrm{~min}$. Thus, the amount of $\mathrm{B}_{2} \mathrm{O}_{3}$ was calculated by subtracting the amount of carbon from the amount of the reactant. The $\mathrm{C} / \mathrm{B}_{2} \mathrm{O}_{3}$ mole ratio $\left(C B_{M}\right)$ of the reactant was measured as follows [35]:

$$
C B_{M}=5.8 \times \frac{\left(D C F_{W}-F_{W}\right)}{\left(R_{W}-D C F_{W}-F_{W}\right)}=5.8 \times \frac{C_{W}}{\left(R_{W}-C_{W}\right)},
$$

where $R_{w}$ is the weight of the reactant, $F_{W}$ is the weight of the filter, and $D C F_{W}$ is the combined weight of the carbon and filter after drying. In addition, $C_{W}$ is the weight of the carbon in the reactant and could be determined through $D C F_{W}-F_{W}[35]$.

The molecular weight of the PVA was determined using a 1260 Infinity II Gel Permeation Chromatography (GPC)/Size Exclusion Chromatography (SEC) System (Agilent Technology). The $\mathrm{pH}$ of each solution was measured using an Isolab, portable $\mathrm{pH} / \mathrm{mV}$ meter. Each solution composition was measured five times and averaged. The viscosity of the solutions was measured using a viscometer (Brookfield Dial Reading, RVT230). The bonding structure of the PVBO was obtained using a Spectrum Two Fourier Transform Infrared (FT-IR) Spectrometer (PerkinElmer) with attenuated total reflectance (ATR) methods. The precursor powders, reactant and $\mathrm{B}_{4} \mathrm{C}$ powder were analyzed through an XRD analysis (Bruker D2 Phaser) with $\mathrm{CuK}_{\alpha}$ radiation. The calcined and filtered powders were observed using SEM/EDS (Phenom) at $20 \mathrm{kV}$. The microstructures of reactants and $\mathrm{B}_{4} \mathrm{C}$ powder were evaluated using fieldemission scanning electron microscopy (FESEM)/EDS (FEI Marka Quanta FEG 450).

\section{RESULT AND DISCUSSION}

\section{Solution densification parameters \\ Concentration of PVA-water solution}

The range of molecular weights of the PVA was measured using GPC as $19000-24015 \mathrm{~g} \cdot \mathrm{mol}^{-1}$. The molecular weight of the polymeric material affects the characteristic properties, such as the viscosity, solubility, stability, water absorption capability, flexibility, and 
crystallinity, during the dehydration-condensation reaction. In addition, the molecular weight is an indicator of the polymeric chain range, decreasing as the molecular weight decreases, and $\mathrm{BO}_{3}$ molecules become unable to find opportunities to bond with carbon on the polymer backbone. Therefore, different $\mathrm{PVA}: \mathrm{H}_{3} \mathrm{BO}_{3}$ compositions were investigated to determine the effects of $\mathrm{PVBO}$ formation on $\mathrm{B}_{4} \mathrm{C}$ production (Table 2). [40].

The degree of hydrolysis is another parameter determining the properties of the polymeric material. If the degree of hydrolysis is low, the water absorption and solubility will increase; however, the viscosity will decreases in the PVA-water solution [41]. In this study, PVA with a hydrolysis degree of 87 - $89 \%$ was used. This type of PVA provides advantages when dissolved in water owing to the low viscosity and high solubility of the PVA, which are required to increase the surface activity between the PVA and $\mathrm{H}_{3} \mathrm{BO}_{3}$ during gelation [37].

The solubility of the PVA may vary with the PVA: $\mathrm{H}_{2} \mathrm{O}$ ratio and temperature. Fully and partially hydrolyzed PVA is soluble in water, depending on the hydrolyzation and degree of polymerization [42]. Fully hydrolyzed PVA (>99\%) only dissolves in hot water, whereas PVA with 87 - $89 \%$ hydrolysis is soluble in both cold and hot water. Fully hydrolyzed PVA contains strong hydrogen bonds among the hydroxyl groups in the PVA molecules after the acetate groups are removed through hydrolyzation. The hydrogen bonds lead to a decrease in the interactions among the molecules in the PVA-water solution because such bonds reduce the solubility of PVA in water. Partially hydrolyzed PVA has acetate groups between the molecules, reducing the binding effect of hydrogen. Therefore, partially hydrolyzed PVA is readily soluble in water, regardless of the temperature [43]. However, the amount of PVA dissolved in water changes depending on the temperature [44]. In a previous study, partially hydrolyzed PVA was dissolved at $80{ }^{\circ} \mathrm{C}$ for $1 \mathrm{~h}$ $[28,38]$. The solubility rate of the PVA in water increases with an increase in the temperature during gel formation,

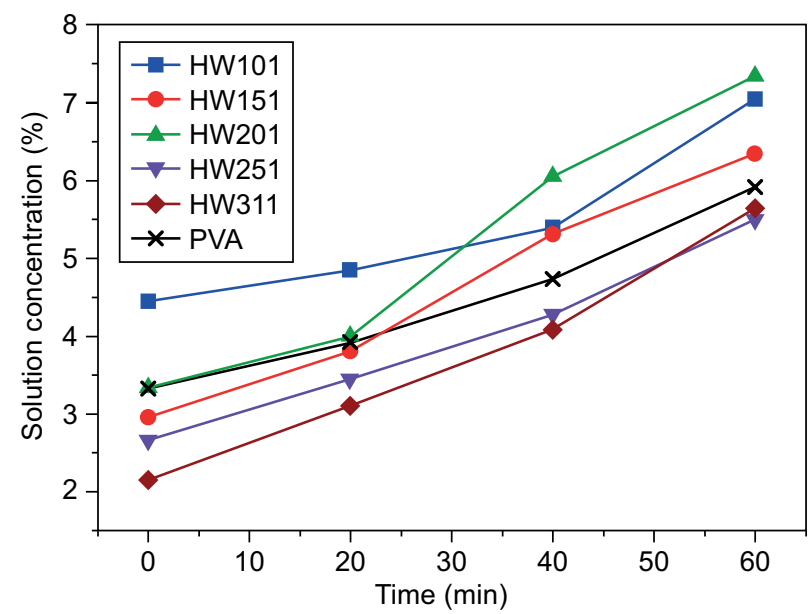

Figure 2. Solution concentration-time curves of $\mathrm{H}_{3} \mathrm{BO}_{3}$ (HW101, HW151, HW201, HW251, HW311) and PVA. increasing the interaction between the PVA and $\mathrm{H}_{3} \mathrm{BO}_{3}$ molecules. Thus, more $\mathrm{H}_{3} \mathrm{BO}_{3}$ can be added to the PVA-water solution during gelation by increasing the temperature [44]. By contrast, the solubility ratio of the PVA in water with an increase in temperature is unstable. The stability of the PVA: $\mathrm{H}_{2} \mathrm{O}$ ratio can be disrupted for a few reasons. First, some of the water evaporates during the heating process. Second, the rate of PVA decreases with the removal of volatiles in the PVA structure. In brief, the PVA-water solution concentration is affected by the evaporating water and volatiles. In this study, the initial PVA: $\mathrm{H}_{2} \mathrm{O}$ ratio in the solution was determined to be 3.3 wt. $\%$. In addition, the average concentration of the PVA was measured as $6.0 \mathrm{wt} . \%$ at the end of the PVA-water solution preparation.

\section{Concentration of $\mathrm{H}_{3} \mathrm{BO}_{3}$-water solution}

Boric acid $\left(\mathrm{H}_{3} \mathrm{BO}_{3}\right)$ starts dehydrating at above $80{ }^{\circ} \mathrm{C}$, and can be transformed into metaboric acid $\left(\mathrm{HBO}_{2}\right)$ [45]. The $\mathrm{H}_{3} \mathrm{BO}_{3}$-water solution was prepared at $60{ }^{\circ} \mathrm{C}$ to prevent it from becoming $\mathrm{HBO}_{2}$ and to allow only $\mathrm{H}_{3} \mathrm{BO}_{3}$ to remain in the water. The ratio of $\mathrm{H}_{3} \mathrm{BO}_{3}$ to distilled water is in the range of $2.15 \mathrm{wt}$. \% to 4.50 wt. $\%$, depending on the PVA: $\mathrm{H}_{3} \mathrm{BO}_{3}$ ratio. The initial ratio of $\mathrm{H}_{3} \mathrm{BO}_{3}$ to distilled water increases owing to the evaporation of the water. Therefore, the initial ratios of the solution should be less than the solubility limit of $\mathrm{H}_{3} \mathrm{BO}_{3}$ in water at $60{ }^{\circ} \mathrm{C}$ owing to the evaporation of water in the solution and the dehydration of $\mathrm{H}_{3} \mathrm{BO}_{3}$. The ratio of $\mathrm{H}_{3} \mathrm{BO}_{3}$ to water is between 4.5 wt. $\%$ and 7.5 wt. $\%$ after the dissolving process. In a previous study, the solubility limit of $\mathrm{H}_{3} \mathrm{BO}_{3}$ in water was shown to be 4.72 wt. $\%$ at $20{ }^{\circ} \mathrm{C}, 15.75$ wt. $\%$ at $70{ }^{\circ} \mathrm{C}$, and 19.10 wt. $\%$ at $80{ }^{\circ} \mathrm{C}$. If $\mathrm{H}_{3} \mathrm{BO}_{3}$ is added to the water at a higher amount than its solubility limit, it cannot dissolve completely during the heating process $[15,46]$. In addition, an excess $\mathrm{H}_{3} \mathrm{BO}_{3}$ concentration prevents a uniform composition dispersion [27]. The highest solution concentration is obtained from the HW201 sample in Figure 2. It can be deduced that the solubility and distribution of $\mathrm{H}_{3} \mathrm{BO}_{3}$ in water is greater than those in the other solutions, and that $\mathrm{H}_{3} \mathrm{BO}_{3}$ can bond to the PVA structure more effectively.

\section{Temperature, viscosity, and $p H$ of PVA-water solution}

Increasing the temperature directly affects the viscosity and solubility of the PVA solution. The aim of heating during the solution step is to increase the solubility, decrease the viscosity, and hinder the agglomeration. Partially hydrolyzed PVA can be dispersed in water at room temperature and partially dissolved, but not completely. Heating is necessary to dissolve PVA. In the literature, fully hydrolyzed PVA was dissolved at $80{ }^{\circ} \mathrm{C}$ for $1 \mathrm{~h}$ [38]. However, the temperature was insufficient to dissolve the PVA. Added water to increase the solubility of the PVA, This further decreased the viscosity [38]. 
As shown in Figure 3, a viscosity of $7.3 \mathrm{cP}$ and a $\mathrm{pH}$ value of 6.25 were measured for a constant PVA-water solution at $80^{\circ} \mathrm{C}$. The $\mathrm{pH}$ value and viscosity of the sol decrease as the temperature increases. Partially hydrolyzed PVA can be dissolved easily in hot distilled water with continuous stirring, and the fluidity is increased. As the viscosity decreases, the mobility and stability of the sol increase at a constant temperature [39]. Thus, the dispersion of particles in the PVA-water solution increases during gelation. Further, lowering the solution viscosity can reduce the amount of $\mathrm{B}_{2} \mathrm{O}_{3}$ and increase its dispersion in the polymeric precursor [37, 38]. In addition, if the PVA-water solution becomes more acidic, the viscosity of the solution decreases and the particle dispersion increases [39]. As a result, $80{ }^{\circ} \mathrm{C}$ was chosen for dissolving the PVA in water and providing the highest dispersion of $\mathrm{H}_{3} \mathrm{BO}_{3}$ in PVA-water solution.

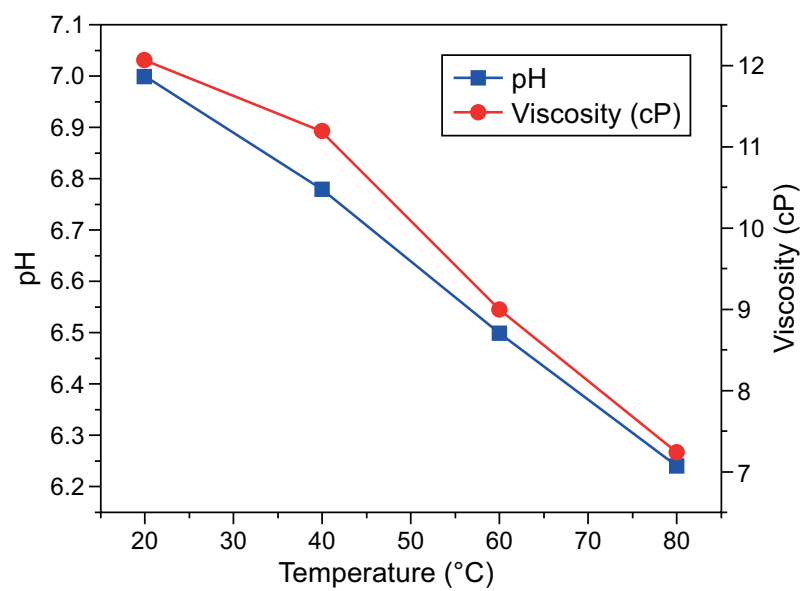

Figure 3. Relationship among temperature, viscosity, and $\mathrm{pH}$ value of PVA-water solution (PVA: $\mathrm{H}_{2} \mathrm{O}$ ratio fixed at all compositions).

\section{Temperature dependence of the $\mathrm{pH}$ of $\mathrm{H}_{3} \mathrm{BO}_{3}$-water solution}

The $\mathrm{H}_{3} \mathrm{BO}_{3}$-water solution is weakly acidic. This property can arise from the following factors. Temperature decreases the $\mathrm{pH}$ values of the PVA-water and $\mathrm{H}_{3} \mathrm{BO}_{3}$-water solutions. Because the water ionizes, the amount of $\mathrm{H}$ ions increases in the solution and the $\mathrm{pH}$ value decreases. In addition, $\mathrm{H}_{3} \mathrm{BO}_{3}$ dissolves in water, and its solubility ratio increases with an increase in temperature. During the dissolution of $\mathrm{H}_{3} \mathrm{BO}_{3}, \mathrm{H}_{2} \mathrm{O}$ molecules and positive ions such as $\mathrm{H}_{3} \mathrm{O}^{+}$are lost. $\mathrm{H}_{3} \mathrm{O}^{+}$ions can decrease the $\mathrm{pH}$ value of the $\mathrm{H}_{3} \mathrm{BO}_{3}$-water solution [47]. The boron alkoxides are hydrolyzed to Reaction 1 and $\mathrm{B}-\mathrm{OH}$ react with $\mathrm{H}^{+}$ions Reaction 2 [39]. Thus, the $\mathrm{pH}$ value of $\mathrm{H}_{3} \mathrm{BO}_{3}$-water can decrease at higher temperatures, and $\mathrm{H}_{3} \mathrm{BO}_{3}$ can bond with PVA more effectively.

$$
\begin{gathered}
\mathrm{B}-\mathrm{OR}+\mathrm{H}_{2} \mathrm{O} \rightarrow \mathrm{B}-\mathrm{OH}+\mathrm{ROH} \\
\mathrm{B}-\mathrm{OH}+\mathrm{H}^{+} \rightarrow \mathrm{B}-\mathrm{OH}_{2}^{+}
\end{gathered}
$$

The $\mathrm{pH}$ value and solution concentration were measured for all samples at $20,40,60^{\circ} \mathrm{C}$. The $\mathrm{pH}$-temperature relationship for all samples during $60 \mathrm{~min}$ process is given in Figure 4. It is observed that the $\mathrm{pH}$ value decreases by increasing the solution temperature, regardless of the composition ratio. However, the amount of $\mathrm{H}_{3} \mathrm{BO}_{3}$ in water affects the $\mathrm{pH}$ value in a decisive way (Higher $\mathrm{H}_{3} \mathrm{BO}_{3}$ leads to decrease the $\mathrm{pH}$ value). Thus, the lowest $\mathrm{pH}$ value and highest solution concentration were obtained from HW101 at different temperatures (Figure 4). The results suggest that $\mathrm{H}_{3} \mathrm{BO}_{3}$ can be more efficiently soluble in water for HW101 sample than the other.

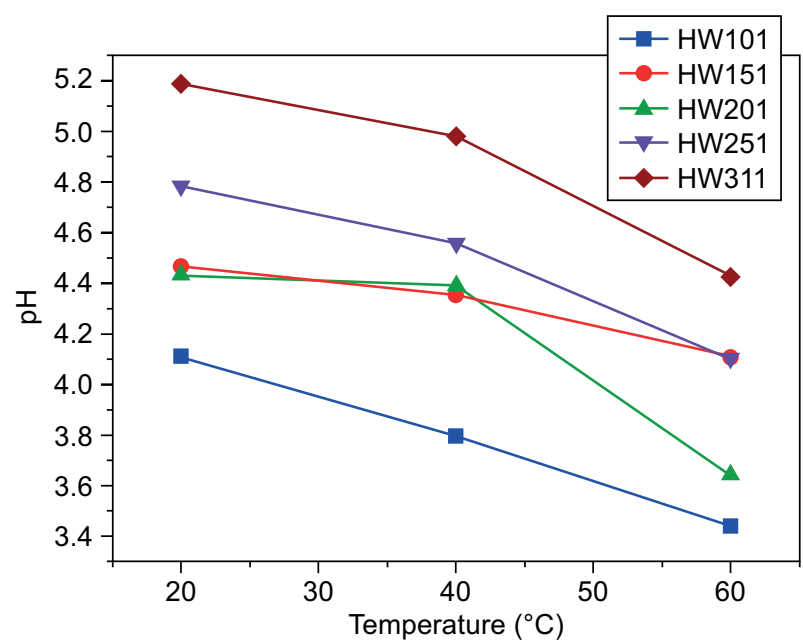

Figure 4. Temperature dependence of the $\mathrm{pH}$ value for all samples during $60 \mathrm{~min}$ process time.

\section{Parameters of PVBO gelation synthesis \\ Effect of temperature on condensation of $P V B O$}

During the gelation process, the $\mathrm{H}_{3} \mathrm{BO}_{3}$ solutions were slowly added to the PVA solutions. The temperature was fixed at $80{ }^{\circ} \mathrm{C}$ to facilitate the dehydration-condensation reactions. The $\mathrm{H}_{3} \mathrm{BO}_{3}$ reacted with the PVA immediately when it was added because the $-\mathrm{OH}$ ions in the $\mathrm{H}_{3} \mathrm{BO}_{3}$ easily bond with the hydroxyl groups in the PVA. The hydrogen bonds provided a cross-linking structure in the PVA chain [48] such that the viscosity increased in the PVA-water solution and produced a gel. When the $\mathrm{H}_{3} \mathrm{BO}_{3}$ solutions were rapidly charged in the PVA solutions, the agglomeration was carried out on the surface of the PVA solution, and $\mathrm{B}-\mathrm{O}$ atoms were unable to react at the interface of the PVA- $\mathrm{H}_{3} \mathrm{BO}_{3}$.

\section{Effect of $\mathrm{pH}$ on condensation of PVBO}

The relationship between the $\mathrm{pH}$ value and the ratio of PVA $/ \mathrm{H}_{3} \mathrm{BO}_{3}$ (see the sample codes in Table 2) the PVA, $\mathrm{H}_{3} \mathrm{BO}_{3}$, and gel is shown in Figure 5. When 
the concentration of $\mathrm{H}_{3} \mathrm{BO}_{3}$ in the $\mathrm{H}_{3} \mathrm{BO}_{3}$-water solution increased, the $\mathrm{pH}$ value of the $\mathrm{H}_{3} \mathrm{BO}_{3}$-water solution decreased due to the increasing acidity of the solution. The ratio of $\mathrm{H}_{3} \mathrm{BO}_{3}$ was higher than in the initial $\mathrm{H}_{3} \mathrm{BO}_{3}: \mathrm{H}_{2} \mathrm{O}$ ratio due to the evaporation of water. The amount of water affects the ratio of concentration and the $\mathrm{pH}$ value. In this study, the water volume of HW311, HW251, HW201 was $30 \mathrm{ml}$, whereas $45 \mathrm{ml}$ of water was used for HW151 and HW101. When the same amount of water $(30 \mathrm{ml})$ was used in all samples, the $\mathrm{H}_{3} \mathrm{BO}_{3}$ was thoroughly dissolved at the start. Later, some of the water in the solution evaporated by heating, and $\mathrm{H}_{3} \mathrm{BO}_{3}$ precipitated owing to the insufficient amount of remaining water, which exceeded the solubility limit of $\mathrm{H}_{3} \mathrm{BO}_{3}$. Therefore, $45 \mathrm{ml}$ of water was used for PHD151 and PHD101.

Ester and complex bonds formed during the reaction between PVA and $\mathrm{H}_{3} \mathrm{BO}_{3}$ via the dehydration-condensation mechanism. In addition, $\mathrm{H}_{3} \mathrm{BO}_{3}$ was unable to react completely with $\mathrm{PVA}$ and remained in the water solution. The higher $\mathrm{H}_{3} \mathrm{BO}_{3}$ ratio provided an increased possibility of a reaction between $\mathrm{PVA}$ and $\mathrm{H}_{3} \mathrm{BO}_{3}$. Further, $\mathrm{H}_{3} \mathrm{BO}_{3}$ was dissolved in water through hydrolysis. Thus, protons were released, and the $\mathrm{pH}$ value of the solution gradually decreased during gelation, see [49]. This situation indicates that the agglomeration decreased. In this study, the $\mathrm{pH}$ value of the PVA solution at $80{ }^{\circ} \mathrm{C}$ is approximately 6.25 . This value could lead to an agglomeration of the PVA when in contact with $\mathrm{H}_{3} \mathrm{BO}_{3}$. The $\mathrm{pH}$ range of the $\mathrm{H}_{3} \mathrm{BO}_{3}$ was 3.5 - 4.5. This ratio provided a more acidic condition during the gelation step, and the agglomeration decreased [39]. However, it was insufficient to prevent the agglomeration during the gel formation. The $\mathrm{pH}$ range of the gel solutions, as shown in Figure 5, was 4.9 - 5.7. In addition, if the $\mathrm{pH}$ value of PVA-water solution becomes more acidic, the particle dispersion increases [39]. In previous studies, the $\mathrm{pH}$ of gel solution was kept below 5.0 [30, 35, 39]. The $\mathrm{pH}$ value of PHD101 was under 5.0 and the $\mathrm{pH}$ value of other

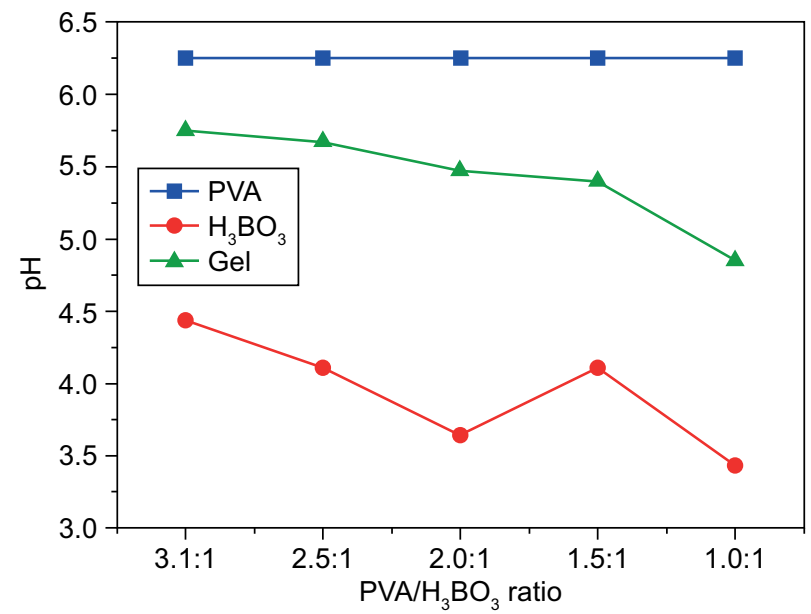

Figure 5. Dependence of the $\mathrm{pH}$ on the $\mathrm{PVA} / \mathrm{H}_{3} \mathrm{BO}_{3}$ ratio for PVA, $\mathrm{H}_{3} \mathrm{BO}_{3}$, and gel. sample was above 5.0. Therefore, the agglomeration of PHD101 took longer than that of the other samples and increased the dispersion of $\mathrm{H}_{3} \mathrm{BO}_{3}$ in the PVA solution and the formation rate of the PVBO.

\section{Effect of time on condensation of $P V B O$}

In previous studies, the condensation process was completed with a thorough evaporation of water [27, $30,36,38]$. The gelation occurred within $5 \mathrm{~min}$, and PVBO was obtained as a white gel. The stirring and heating processes were continued until the water was completely evaporated. During PVBO formation, the hydroxyl groups, which separated from $\mathrm{H}_{3} \mathrm{BO}_{3}$, bonded to the $\mathrm{C}$ atoms in the PVA chain. However, not all $\mathrm{H}_{3} \mathrm{BO}_{3}$ dissolved in water was able to react with the PVA gel within $5 \mathrm{~min}$, and some of the dissolved $\mathrm{H}_{3} \mathrm{BO}_{3}$ remained in the aqueous solution. In other words, not all boron atoms were able to contact the $\mathrm{C}$ atoms initially. Thus, the product of the condensation process was analyzed at different holding times.

First, we determined three different conditions according to the time and water evaporation conditions. The first and second conditions were based on the completion of the process at 5 and $60 \mathrm{~min}$, respectively. The third condition was based on the complete evaporation of the water after gel formation. The gel structure varied with the condensation time. When the gel was taken from the beaker at 5 or $60 \mathrm{~min}$, the gel structure became sponge like. When the water was allowed to evaporate completely, the structure of the gel became rubbery and was coated with a $\mathrm{H}_{3} \mathrm{BO}_{3}$ powder. In addition, the weights of the gels formed were measured after 5 min of condensation and after the completion of the evaporation. It was shown that the gel weight is greater after the short-term condensation process in Figure 6 . The longer condensation process promoted a lighter gel weight. PVA underwent high water absorption and the solution absorbed the water during the condensation reaction. The gel was constantly exposed to stirring and

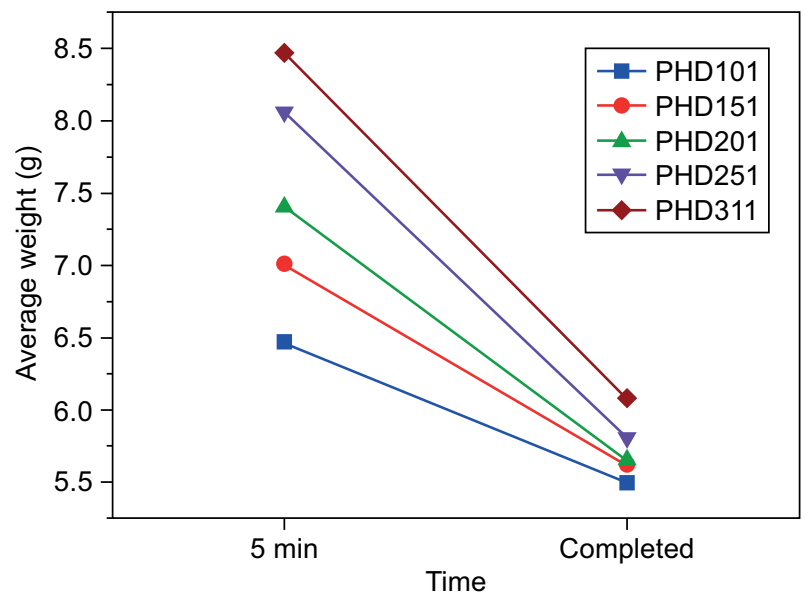

Figure 6. Relationship between average gel weight and PVBO formation time in PHD samples. 
an applied temperature during a longer processing time. During this time, the gel formed left the absorption water and became more rigid. All samples contain the same amount of PVA. For this reason, the water absorption behavior can be expected to be similar for each sample, and the average gel weight is expected to be very close. However, the average gel weight is different for all samples presumably because of the different amount of $\mathrm{H}_{3} \mathrm{BO}_{3}$. The variation of samples weight can be attributed to the effect of $\mathrm{H}_{3} \mathrm{BO}_{3}$. PHD101 contain the highest amount of $\mathrm{H}_{3} \mathrm{BO}_{3}$, and the lightest amount of gel weight was obtained from it, regardless of gelation time. In addition, as the $\mathrm{H}_{3} \mathrm{BO}_{3}$ ratio decreases in the samples, the gelation weight increases. For these reason, it can be deduced that higher amount of $\mathrm{H}_{3} \mathrm{BO}_{3}$ can be bonded with PVA much more easily and prevent the water absorption of PVA.

When the gelation process was finished and the gel was removed, aqueous solution remained under the first and second conditions, whereas a sediment was observed under the third condition. The remaining aqueous solutions were fully dehydrated at $120{ }^{\circ} \mathrm{C}$, and the deflocculated products also settled in the form of

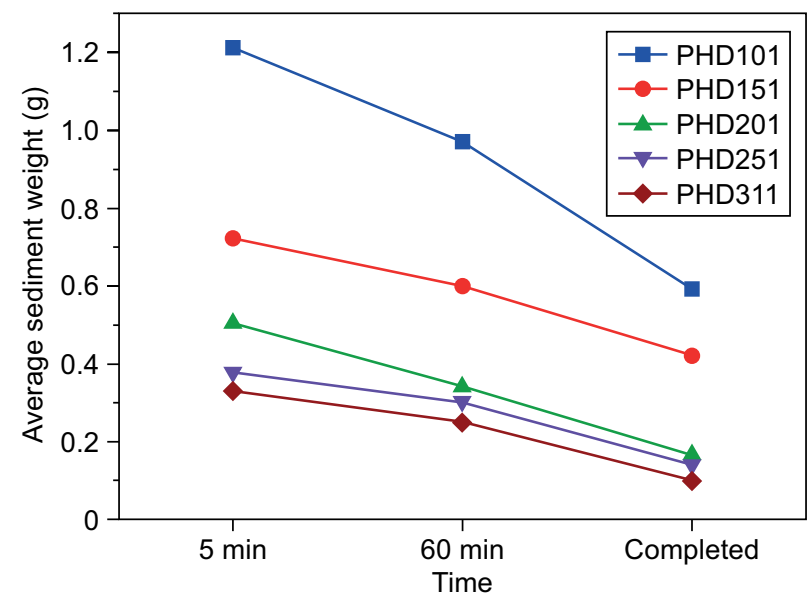

Figure 7. Relationship between sediment weight and time of the PVBO synthesis process in PHD samples.

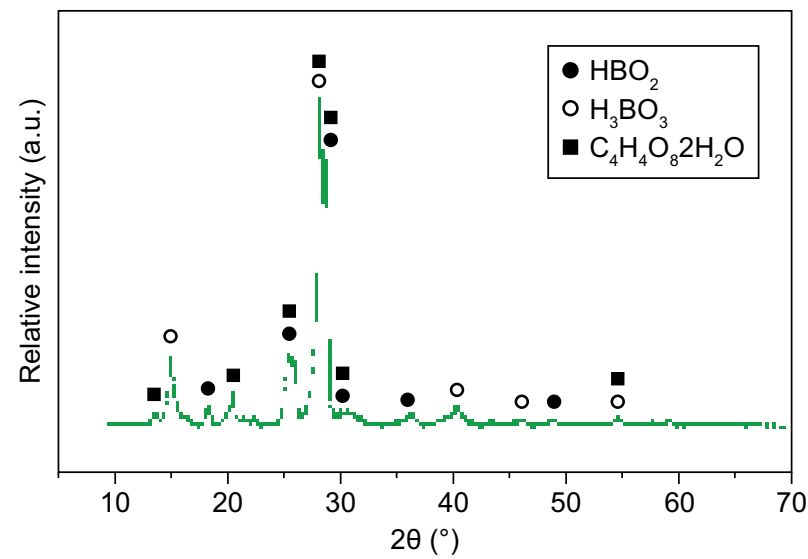

Figure 8. XRD pattern (diffractogram) of the sediment after drying at $120^{\circ} \mathrm{C}$ for PHD101. sediments. All sediments were weighed. The difference in weight between the sediment samples with respect to time is shown in Figure 7. Most of the sediment measured was in PHD101, which included the highest amount of $\mathrm{H}_{3} \mathrm{BO}_{3}$ among the samples. All samples contained the same amount of PVA and the same PVA "structural capacity" in terms of bonding to $\mathrm{H}_{3} \mathrm{BO}_{3}$. This capacity is maximized in the PHD101 sample, in which a higher amount of $\mathrm{H}_{3} \mathrm{BO}_{3}$ appears as a sediment than in the other samples. Therefore, excessive $\mathrm{H}_{3} \mathrm{BO}_{3}$ could not bond to the PVA and remained in the PVA- $\mathrm{H}_{3} \mathrm{BO}_{3}$ gel solution. The average amount of sediment also decreased as the amount of $\mathrm{H}_{3} \mathrm{BO}_{3}$ gradually decreased. The ratio of the condensation reaction could increase between the $\mathrm{H}_{3} \mathrm{BO}_{3}$ and PVA molecules with respect to temperature and time. In addition, the partially hydrolyzed PVA absorbed much more water during dissolution. It could lose water from the structure and increase contact with more of the $\mathrm{H}_{3} \mathrm{BO}_{3}$ molecules. Thus, the amount of sediment should decrease over time.

The XRD pattern of the sediment for PHD101 is shown in Figure 8. The sediment contained $\mathrm{HBO}_{2}$, $\mathrm{H}_{3} \mathrm{BO}_{3}$, and $\mathrm{C}_{4} \mathrm{H}_{4} \mathrm{O}_{6} \cdot 2 \mathrm{H}_{2} \mathrm{O}$ phases. The intensities of the peaks of all crystalline phases in the XRD were high. In addition, $\mathrm{H}_{3} \mathrm{BO}_{3}$ in the XRD diffractogram came from initial $\mathrm{H}_{3} \mathrm{BO}_{3}$, and did not react with the partially hydrolyzed PVA. When the $\mathrm{H}_{3} \mathrm{BO}_{3}$ powder did not react with the PVA, it remained in the sediment, which consisted of a mixture of $\mathrm{H}_{3} \mathrm{BO}_{3}$ and PVA powder. The $\mathrm{H}_{3} \mathrm{BO}_{3}$ was dehydrated at $120{ }^{\circ} \mathrm{C}$ during the drying process. Therefore, it transformed into an $\mathrm{HBO}_{2}$ phase. The partially hydrolyzed PVA consisted of $\mathrm{C}_{4} \mathrm{H}_{6} \mathrm{O}_{2}$ and $\mathrm{C}_{2} \mathrm{H}_{4} \mathrm{O}$. Phase peaks of $\mathrm{C}_{4} \mathrm{H}_{4} \mathrm{O}_{6} \cdot 2 \mathrm{H}_{2} \mathrm{O}$ in the XRD pattern formed as a result of the reaction between PVA and $\mathrm{H}_{2} \mathrm{O}$. The XRD spectra of the sediment primarily included crystalline phases. Thus, it was deduced that the ratio of PVA could be lower than the ratios of $\mathrm{H}_{3} \mathrm{BO}_{3}$ and any other borate phases in the sediment, and a large amount of PVA was passed to the gel structure.

\section{Investigation of PVBO $X R D$ analysis}

PVA is a semicrystalline material. $\mathrm{H}_{3} \mathrm{BO}_{3}$ bonds to the amorphous region of the PVA and $\mathrm{H}_{3} \mathrm{BO}_{3}$ increases the chain length of the amorphous structure [50]. XRD analyses of the PVA and PVBO are shown in Figure 9. The characteristic peak of the PVA is observed at $2 \theta=$ $=19.5^{\circ}$. This peak also appears in the PVBO samples, but in a much more broadened form, which shows that an esterification reaction occurs between the $\mathrm{H}_{3} \mathrm{BO}_{3}$ and PVA. As to the $2 \theta=40^{\circ}$ peak, it disappears in the PVBO samples. All sample peak intensities and widths are extremely similar, and thus it is difficult to assess the formation rate of the PVBO with respect to the initial composition ratio. Mondal ve Banthia et al. [22] analyzed the polymeric precursor structure using 
$\mathrm{XRD}$, and observed some crystalline peaks in the diffraction pattern. In this study, only one peak $\left(2 \theta=28^{\circ}\right)$ was observed in the XRD analysis for PHD201, and all PVBO samples showed generally amorphous characteristics. A large hump $\left(2 \theta=19.5^{\circ}\right)$ was observed only in the XRD pattern of the PVBO [29]. Barros et al. [29] reported such a diffraction pattern attributing it to the semi-crystalline structure of the polymeric precursor. As a result, similar XRD patterns were observed in this study for the PVBO samples. Therefore, according to the $\mathrm{XRD}$ analysis, it can be deduced that the synthesis of PVBO was successful.

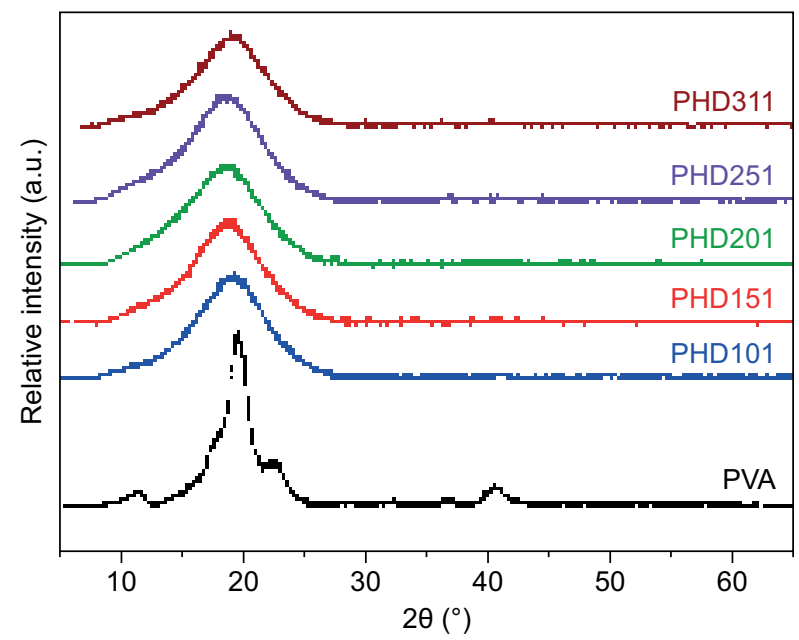

Figure 9. XRD analyses of PVBO.

\section{FTIR analysis}

According to the XRD analyses, PVBO was synthesized from all PHD samples. The sample containing the highest proportion of $\mathrm{H}_{3} \mathrm{BO}_{3}$, i.e., HW101, had the highest solution concentration, and its $\mathrm{pH}$ was lower than that of the other samples. This led to a decrease in the $\mathrm{pH}$ of $\mathrm{PVA}-\mathrm{H}_{3} \mathrm{BO}_{3}$, which was the solution with the lowest-pH, during the gelation. The solution became more acidic and the degree of agglomeration decreased compared to the other samples. Therefore, the dispersion of $\mathrm{H}_{3} \mathrm{BO}_{3}$ in the PVA was higher than in the other solutions. In addition, as the amounts of $\mathrm{H}_{3} \mathrm{BO}_{3}$ increase in a sample, it can be bonded with PVA further and prevent the water absorption of PVA (Figure 6). As a result, the study continued based on the PHD101 sample, which was investigated using FTIR to prove the formation of PVBO.

The FTIR spectra of $\mathrm{H}_{3} \mathrm{BO}_{3}$, PVA, and PHD101 are shown in Figure 10. The $\mathrm{O}-\mathrm{H}$ stretching vibrations appeared at absorption bands of $3000-3500 \mathrm{~cm}^{-1}$ for $\mathrm{H}_{3} \mathrm{BO}_{3}, \mathrm{PVA}$, and $\mathrm{PVBO}$. If the $\mathrm{O}-\mathrm{H}$ bond peaks are lower at the PVBO spectrum, this indicates that esterification reactions occur between the PVA and $\mathrm{H}_{3} \mathrm{BO}_{3}$. However, there are unreacted $\mathrm{O}-\mathrm{H}$ bonds in the PVBO [27, 34]. The absorption peak at $1450 \mathrm{~cm}^{-1}$ is attributed to the $\mathrm{B}-\mathrm{O}$ bonds [22]. These peaks can be seen in both the PVBO and $\mathrm{H}_{3} \mathrm{BO}_{3}$ but are smaller in the PVBO. In addition, $\mathrm{C}-\mathrm{O}-\mathrm{C}$ bonds are observed in the absorption bands at $\sim 1250 \mathrm{~cm}^{-1}$ in the PVA spectra, but are absent in the PVBO. The B-O-H bonds appear at $\sim 1190 \mathrm{~cm}^{-1}$ in the $\mathrm{H}_{3} \mathrm{BO}_{3}$ spectra and can be seen in the PVBO spectra, because $\mathrm{B}-\mathrm{O}-\mathrm{H}$ bonds are maintained in the PVBO [35]. Some $\mathrm{H}_{3} \mathrm{BO}_{3}$ molecules could not react with the PVA and remained in the PVBO structure. Moreover, the peak at $2952 \mathrm{~cm}^{-1}$ is referred to the aliphatic vibration of the $\mathrm{C}-\mathrm{H}$ bonds, which are not found in the PVBO spectra [22]. The $1287 \mathrm{~cm}^{-1}$ and $1080 \mathrm{~cm}^{-1}$ absorption peaks were ascribed to the $\mathrm{B}-\mathrm{O}-\mathrm{C}$ bonds, which are the main evidence for the formation of PVBO [26, 27, 31, 34]. Therefore, condensation reactions were executed between the PVA and $\mathrm{H}_{3} \mathrm{BO}_{3}$. The $\mathrm{C}-\mathrm{H}$ peaks were not seen in PHD101, which contained the highest amount of $\mathrm{H}_{3} \mathrm{BO}_{3}$ among all samples. $\mathrm{C}-\mathrm{H}$ peaks were present in the PVA. The $\mathrm{C}-\mathrm{O}-\mathrm{C}$ and $\mathrm{B}-\mathrm{O}-\mathrm{H}$ bands disappeared in the PVBO sample. The intensity of the peaks gradually decreased because of the decreasing $\mathrm{H}_{3} \mathrm{BO}_{3}$ content. The $\mathrm{C}-\mathrm{O}$ from the PVA and $\mathrm{B}-\mathrm{O}-\mathrm{H}$ from the $\mathrm{H}_{3} \mathrm{BO}_{3}$ bands intensity decreased in the PHD101. As a result, PHD101 is preferred for further analysis because $\mathrm{H}_{3} \mathrm{BO}_{3}$ is bonded with the PVA structure and the formation of PVBO is maximized.

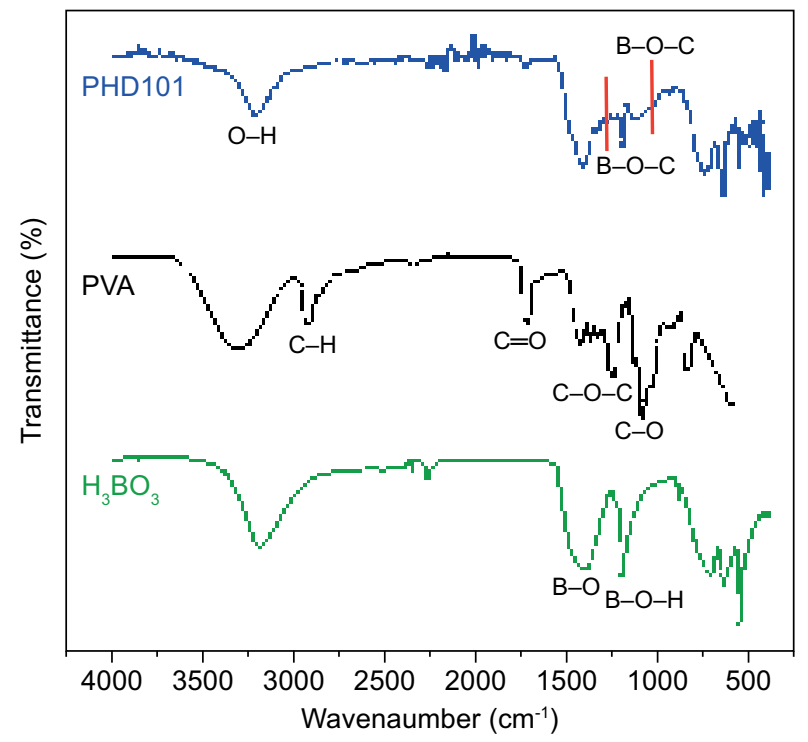

Figure 10. Comparison of FTIR spectra of $\mathrm{H}_{3} \mathrm{BO}_{3}$, PVA and PHD101.

\section{Calcination}

The polymeric precursor was calcined to decompose the organic compounds. Borate ester bonds in the polymeric precursor were destroyed through heat treatment and yielded a reactant composed of finely distributed $\mathrm{B}_{2} \mathrm{O}_{3}$ in a $\mathrm{C}$ matrix. Thus, the single-source reactant served as a carbon and boron source for $\mathrm{B}_{4} \mathrm{C}$ 
synthesis. SEM images of the PHD101 reactant and $\mathrm{B}_{2} \mathrm{O}_{3}$ leaching from the reactant are shown in Figure 11a and $b$, respectively. Five points are shown on the SEM images and their EDS analysis results are listed in Table 3 . At points 1 and 4, both $\mathrm{B}$ and $\mathrm{O}$ were detected, indicating the presence of $\mathrm{B}_{2} \mathrm{O}_{3}$. At points 2 and $3, \mathrm{~B}, \mathrm{O}$, and $\mathrm{C}$ were observed, which indicates that the product consisted of $\mathrm{B}_{2} \mathrm{O}_{3}$ and carbon. At point $5, \mathrm{~B}_{2} \mathrm{O}_{3}$ molecules were dissolved by hot water and left the carbon matrix, and thus a significant number of carbon atoms can be seen in the EDS analysis results.

The molar ratio of $\mathrm{C} / \mathrm{B}_{2} \mathrm{O}_{3}$ stoichiometric $\mathrm{B}_{4} \mathrm{C}$ synthesis should be 3.5 , according to reaction 3 .

$$
2 \mathrm{~B}_{2} \mathrm{O}_{3}+7 \mathrm{C} \rightarrow \mathrm{B}_{4} \mathrm{C}+\mathrm{CO}
$$

However, $\mathrm{B}_{2} \mathrm{O}_{3}$ transforms into boron suboxides with heat. The boron suboxides are in a vapor phase at above $1050{ }^{\circ} \mathrm{C}$ and leave a reaction zone [22, 27]. Therefore, the molar ratio of $\mathrm{C} / \mathrm{B}_{2} \mathrm{O}_{3}$ should be less

Table 3. EDS analysis results of PHD101.

\begin{tabular}{cccc}
\hline $\begin{array}{c}\text { EDS } \\
\text { points }\end{array}$ & $\begin{array}{c}\text { Element } \\
\text { symbol }\end{array}$ & $\begin{array}{c}\text { Atomic } \\
\text { conc. (\%) }\end{array}$ & $\begin{array}{c}\text { Weight } \\
\text { conc. (\%) }\end{array}$ \\
\hline \multirow{2}{*}{1} & O & 70.38 & 77.86 \\
& B & 29.62 & 22.14 \\
\hline \multirow{2}{*}{2} & C & 59.51 & 54.32 \\
& O & 31.47 & 38.27 \\
& B & 9.01 & 7.40 \\
\hline \multirow{3}{*}{3} & C & 61.40 & 55.68 \\
& O & 32.72 & 39.52 \\
& B & 5.88 & 4.80 \\
\hline \multirow{2}{*}{4} & O & 75.14 & 81.73 \\
& B & 24.86 & 18.27 \\
\hline \multirow{2}{*}{5} & C & 69.13 & 62.26 \\
& O & 30.48 & 36.57 \\
& Ca & 0.39 & 1.17 \\
\hline
\end{tabular}

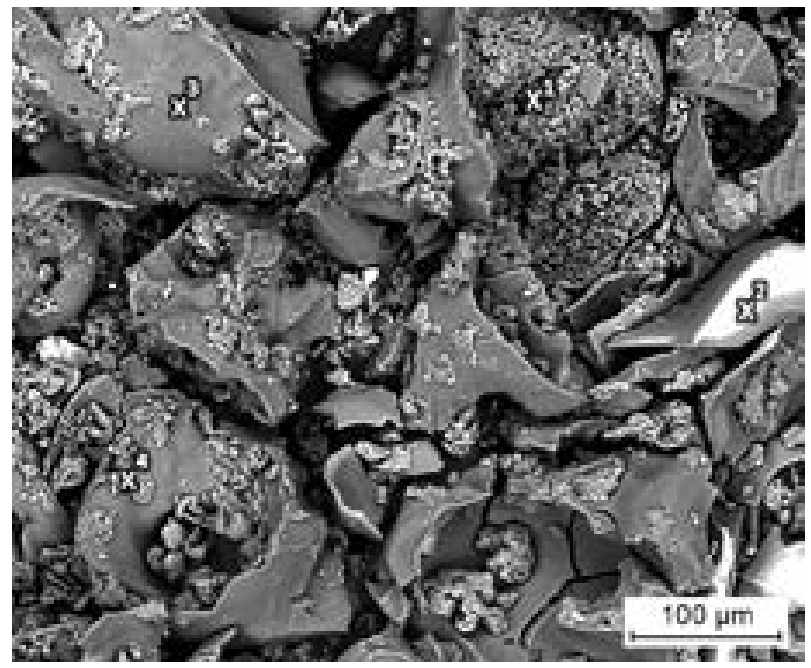

a) than 3.5 to compensate for the volatile boron suboxide. Yanase et al. [27] reported that calcination should be performed at $600{ }^{\circ} \mathrm{C}$ in air for $2 \mathrm{~h}$ to optimize the $\mathrm{C} / \mathrm{B}_{2} \mathrm{O}_{3}$ molar ratio, which was measured as approximately 3.3. In previous studies, it was suggested that $\mathrm{C} / \mathrm{B}_{2} \mathrm{O}_{3}$ should be approximately $2.9-3.5[28,37]$. The composition of the initial raw materials should be adjusted to the molar ratio of $\mathrm{C} / \mathrm{B}_{2} \mathrm{O}_{3}$.

The calcination step was applied at 500, 600, and $700{ }^{\circ} \mathrm{C}$ in air for $1-3 \mathrm{~h}$. Calcination was conducted at above $400{ }^{\circ} \mathrm{C}$ in order to decompose of the polymeric precursor and remaining polymeric groups [37]. The process was executed in air according to [51]. The free carbon content in $\mathrm{B}_{4} \mathrm{C}$ could be reduced via carbothermal reduction of the reactants below $1800{ }^{\circ} \mathrm{C}$, leading to a homogeneous and uniform reactant component distribution [38]. The range of the $\mathrm{C} / \mathrm{B}_{2} \mathrm{O}_{3}$ ratios was calculated for the PHD101 sample, as listed in Table $4 . \mathrm{H}_{3} \mathrm{BO}_{3}$ either enters the gel structure molecularly via a condensation reaction with the PVA or adheres to the gel as a particle and remains in the gel structure. As a result, the $\mathrm{C} / \mathrm{B}_{2} \mathrm{O}_{3}$ ratio is unstable. The $\mathrm{C} / \mathrm{B}_{2} \mathrm{O}_{3}$ ratio of samples were measured and calculated according to the condensation process ( $5 \mathrm{~min}$ and complete water evaporation). We determined the range of $\mathrm{C} / \mathrm{B}_{2} \mathrm{O}_{3}$ for each calcination temperature and time. We observed that the amounts of carbon and $\mathrm{B}_{2} \mathrm{O}_{3}$ vary with the gelation time, obviously because the condensation reactions between PVA and $\mathrm{H}_{3} \mathrm{BO}_{3}$ continue during the gelation. When excessive

Table 4. $\mathrm{C} / \mathrm{B}_{2} \mathrm{O}_{3}$ ratio in the reactant from PHD101.

\begin{tabular}{cccc}
\hline \multirow{2}{*}{$\begin{array}{c}\text { Time } \\
\text { (h) }\end{array}$} & 500 & 600 & 700 \\
\hline 1 & $3.98-1.96$ & $2.93-1.20$ & $2.24-0.66$ \\
2 & $3.34-1.80$ & $2.50-0.96$ & $1.79-0.57$ \\
3 & $3.01-1.64$ & $2.32-0.80$ & $1.71-0.46$ \\
\hline
\end{tabular}

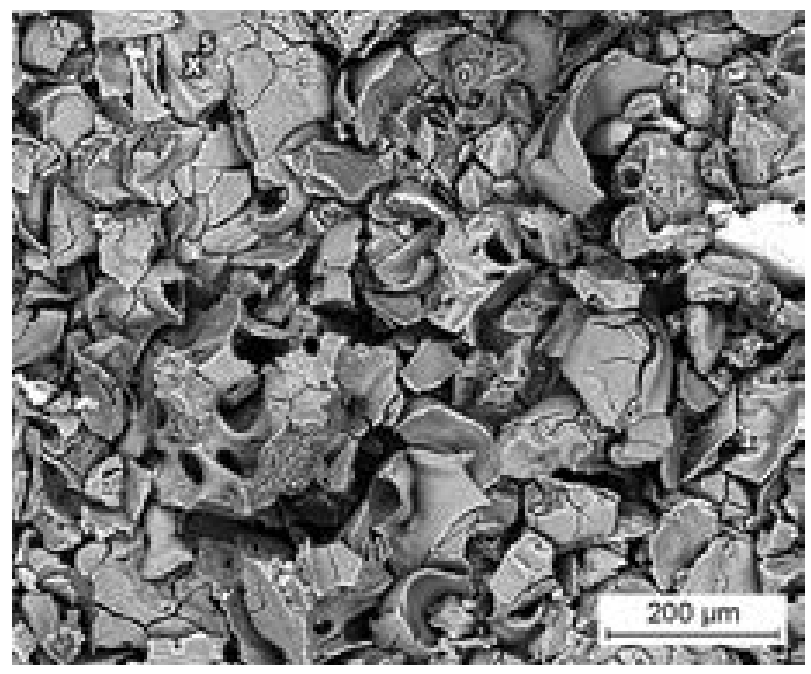

b)

Figure 11. SEM images of: a) PHD101 reactant calcined at $500{ }^{\circ} \mathrm{C}$ for $2 \mathrm{~h}$ and b) $\mathrm{B}_{2} \mathrm{O}_{3}$ dissolved for the same sample. 
$\mathrm{H}_{3} \mathrm{BO}_{3}$ is present in the solution, the PVA cannot react with all dissolved $\mathrm{H}_{3} \mathrm{BO}_{3}$. The remaining $\mathrm{H}_{3} \mathrm{BO}_{3}$ powder is deposited on the gel surface formed. Therefore, the ratios of $\mathrm{C} / \mathrm{B}_{2} \mathrm{O}_{3}$ change with gelation time. Based on literature data [28, 37], a calcination temperature of $500{ }^{\circ} \mathrm{C}$ with a dwell time of $2 \mathrm{~h}$ was chosen for achieving an optimum ratio of $\mathrm{C} / \mathrm{B}_{2} \mathrm{O}_{3}$ for in the PHD101 sample.

The FESEM image of the PHD101 sample after extraction of $\mathrm{B}_{2} \mathrm{O}_{3}$ from the reactant is given in Figure 12 . The PVA has a reticulated structure that affects the distribution of $\mathrm{H}_{3} \mathrm{BO}_{3}$ molecules [28]. After calcination, the structure is responsible for the distribution of $\mathrm{B}_{2} \mathrm{O}_{3}$ in the carbon structure. The reactant was washed in hot water. The $\mathrm{B}_{2} \mathrm{O}_{3}$ then dissolved and left the carbon matrix. A porous structure could be seen in the carbon matrix. The estimated pore size distribution of FESEM image obtained from the reactant is given Figure 13. The pore size distribution was non-uniform, with an average pore size was of approximately $150 \mathrm{~nm}$. $\mathrm{B}_{2} \mathrm{O}_{3}$ was

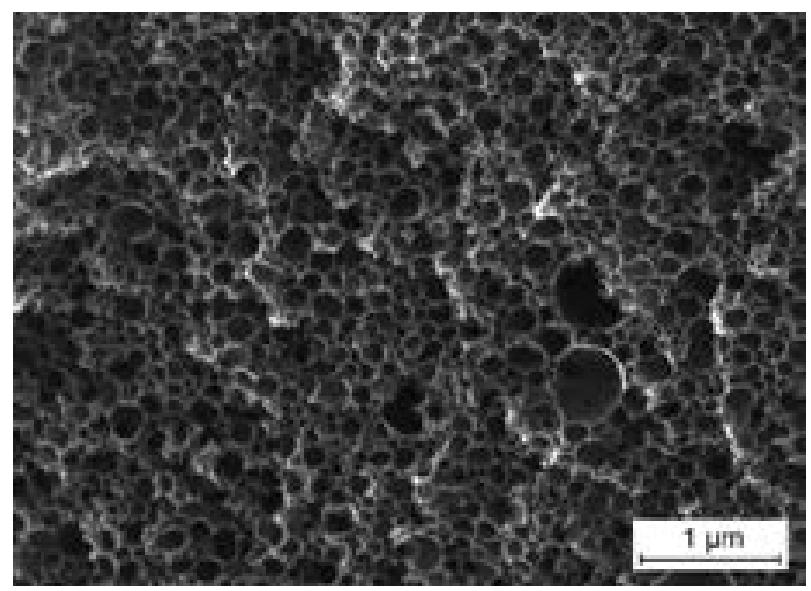

Figure 12. FESEM image of PHD101 sample after calcination at $500{ }^{\circ} \mathrm{C}$ for $2 \mathrm{~h}$ (after $\mathrm{B}_{2} \mathrm{O}_{3}$ was extracted from the $\mathrm{C} / \mathrm{B}_{2} \mathrm{O}_{3}$ reactant).

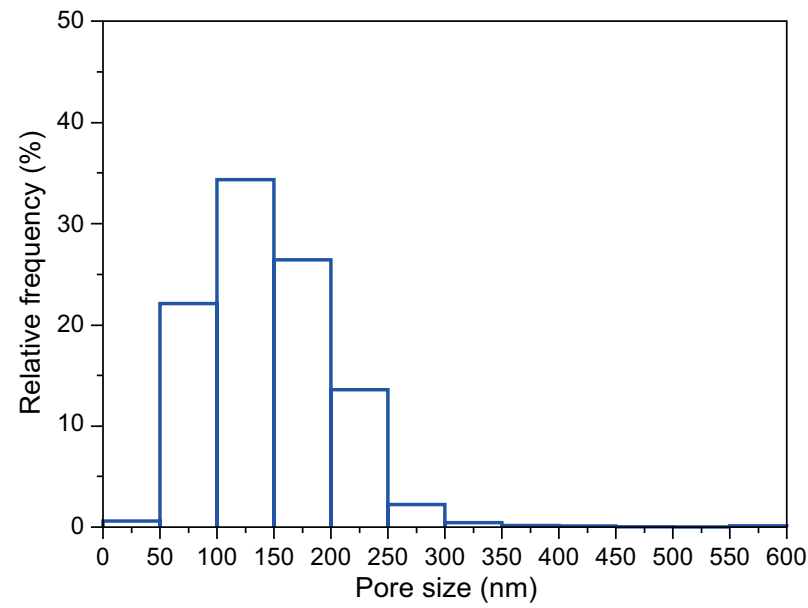

Figure 13. Pore size distribution of PHD101 sample at $500{ }^{\circ} \mathrm{C}$ for $2 \mathrm{~h}$ calcination after $\mathrm{B}_{2} \mathrm{O}_{3}$ was extracted from the $\mathrm{C} / \mathrm{B}_{2} \mathrm{O}_{3}$ reactant estimated from FESEM image. distributed nearly homogeneously on the nano-scale level in the carbon matrix (Figure 12). Some larger pores can be seen in the image because unreacted $\mathrm{H}_{3} \mathrm{BO}_{3}$ powder with the PVA-water solution precipitated and remained in the PVBO gel. The $\mathrm{H}_{3} \mathrm{BO}_{3}$ powder was calcined and transformed into $\mathrm{B}_{2} \mathrm{O}_{3}$. These pores formed by dissolution of $\mathrm{B}_{2} \mathrm{O}_{3}$ in water at $80^{\circ} \mathrm{C}$.

\section{$\mathrm{B}_{4} \mathrm{C}$ synthesis}

The XRD pattern of PHD101 after calcination at $500{ }^{\circ} \mathrm{C}$ for $2 \mathrm{~h}$ is given in Figure $14 \mathrm{a}$. The peaks of $\mathrm{B}_{2} \mathrm{O}_{3}$ and $\mathrm{C}$ are clearly seen on the XRD pattern. These peaks provide correlation with SEM analysis of reactant in Table 3. In addition, $\mathrm{H}_{3} \mathrm{BO}_{3}$ phase is found the reactant structure. Probably, this $\mathrm{H}_{3} \mathrm{BO}_{3}$ phase results from $\mathrm{B}_{2} \mathrm{O}_{3}$ being in contact with moisture in the air. After heat treatment at $1400{ }^{\circ} \mathrm{C}$ for $5 \mathrm{~h}$ the $\mathrm{B}_{2} \mathrm{O}_{3}$ has disappeared and amount of carbon is has decreased (Figure 14), indicating that $\mathrm{B}_{2} \mathrm{O}_{3}$ has reacted with carbon according to reaction (3) to form $\mathrm{B}_{4} \mathrm{C}$. An XRD pattern is shown in Figure $14 \mathrm{~b}$, where the crystalline peaks of $\mathrm{B}_{4} \mathrm{C}$ are clearly observed. Silicon Carbide ( $\mathrm{SiC}$ ) has formed as an impurity. Also the free carbon can be considered as an impurity. The $\mathrm{B}_{2} \mathrm{O}_{3}$, which is in the reactant, can be transformed into vapor phase suboxides and might leave the reactant structure. Therefore, the carbon is unable to find enough $\mathrm{B}_{2} \mathrm{O}_{3}$ to react quantitatively and remains as free carbon in the $\mathrm{B}_{4} \mathrm{C}$ material. The $\mathrm{B}_{4} \mathrm{C}$ crystalline size was determined by the Scherrer equation. The calculated average crystallite size was $24 \mathrm{~nm}$.

The SEM/EDS analysis is shown in Figure 15. Si was observed in the EDS analysis, and the XRD and EDS

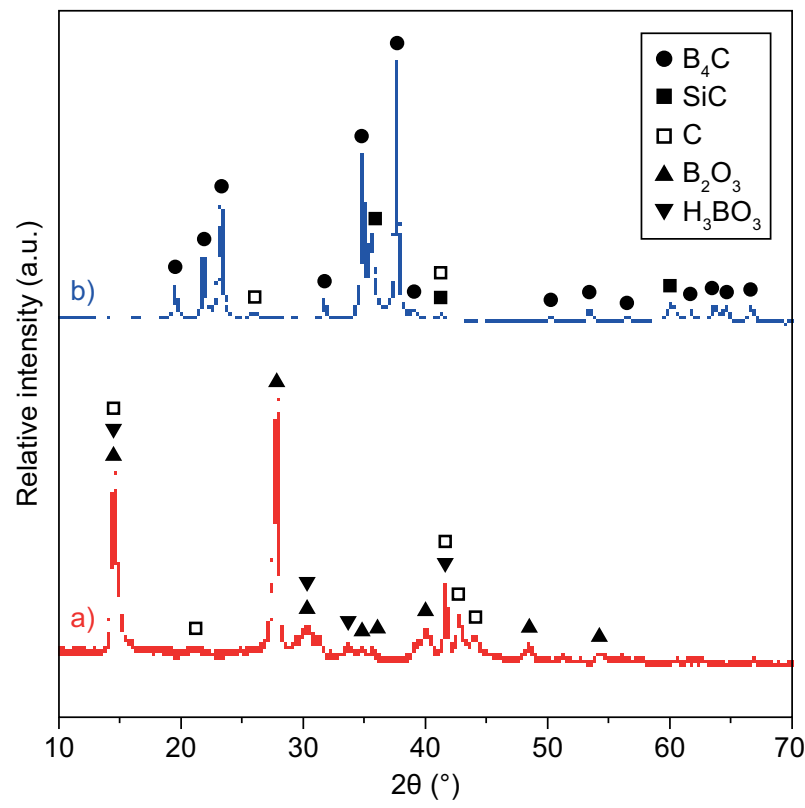

Figure 14. XRD analysis of PHD101 sample after heat treatment at $1400{ }^{\circ} \mathrm{C}$ for $5 \mathrm{~h}$ (a), before calcination at $500{ }^{\circ} \mathrm{C}$ for $2 \mathrm{~h}(\mathrm{~b})$. 
analyses provide a correlation of the presence of $\mathrm{Si}$ in the product, which must be considered as a result of contamination. Moreover, aluminum was found in the EDS analysis (however, no aluminum-containing was detected by XRD analysis.) This is probably a contamination

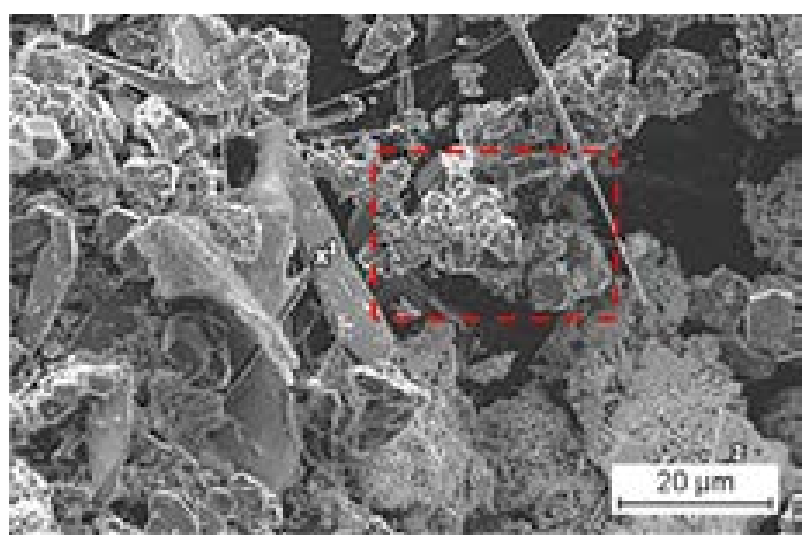

a)

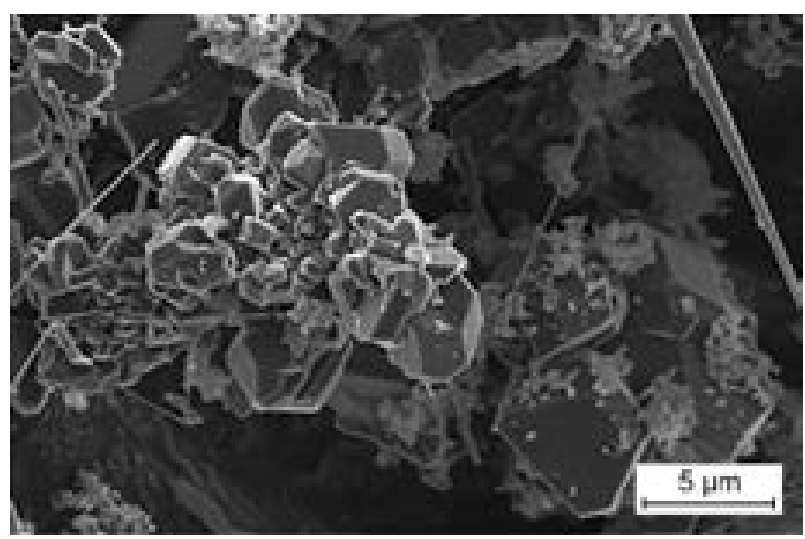

b)
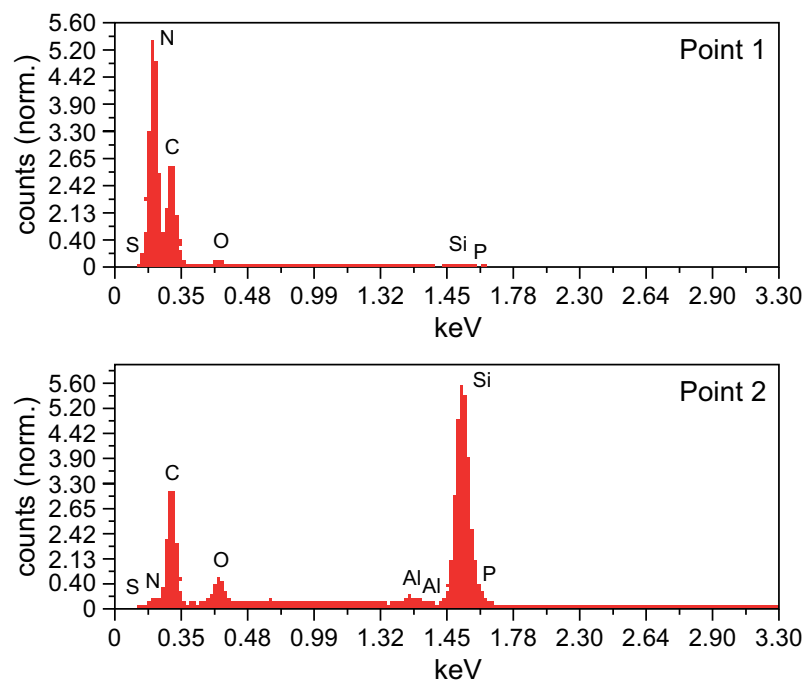

c)

Figure 15. a) SEM micrograph, b) magnified area which marked with red rectangle dashed lines in (a), and c) EDS analysis of PHD101 sample after heat treatment at $1400{ }^{\circ} \mathrm{C}$ for $5 \mathrm{~h}$ (before calcination at $500{ }^{\circ} \mathrm{C}$ for $2 \mathrm{~h}$.) coming from the alumina crucible. The $\mathrm{B}_{4} \mathrm{C}$ structure can clearly be seen in the SEM analysis, and the EDS peaks confirm this composition. However, some parts of the structure is covered with whitish particles, which were analyzed using EDS and identified as having a Si peak higher than the $\mathrm{B}$ peak. SiC accumulated over the $\mathrm{B}_{4} \mathrm{C}$ structure and entered the structure during the reduction reactions.

Polygonal grains were found in the morphology of the sample (Figure 15a, b). These grains forms aggregated particles, comprising both fine and irregular shapes. The particle size distribution was extremely wide. In addition, polyhedral, needle-like, and flake-like particles were observed. Different morphological shapes can be the results of different nucleation mechanism. Polyhedral $\mathrm{B}_{4} \mathrm{C}$ is expected to arise from the synthesis reaction between liquid $\mathrm{B}_{2} \mathrm{O}_{3}$ and solid carbon [52], whereas needlelike and flake-like $\mathrm{B}_{4} \mathrm{C}$ particles are expected to form via vapor and solid mechanisms between the $\mathrm{B}_{2} \mathrm{O}_{3}$ and carbon molecules. As a result, a morphologically nonuniform $\mathrm{B}_{4} \mathrm{C}$ material was synthesized by heat treatment at $1400{ }^{\circ} \mathrm{C}$ for $5 \mathrm{~h}$.

\section{CONCLUSION}

In this study, industrial raw materials, including partially hydrolyzed PVA and technical-grade $\mathrm{H}_{3} \mathrm{BO}_{3}$, were used for $\mathrm{B}_{4} \mathrm{C}$ synthesis using a polymeric precursor method distinct from that applied in existing studies (in terms of raw materials). PVBO was produced through a sol-gel method. The condensation process parameters were investigated, including the $\mathrm{pH}$ value and viscosity, and the temperature was determined based on the composition ratio during the solution preparation process. A viscosity of $7.3 \mathrm{cP}$ and a $\mathrm{pH}$ of 6.25 were measured for a constant PVA-water solution at $80{ }^{\circ} \mathrm{C}$. The solubility of $\mathrm{H}_{3} \mathrm{BO}_{3}$ for different compositions increased when the temperature was increased. The sample containing the highest proportion of $\mathrm{H}_{3} \mathrm{BO}_{3}$, i.e., $\mathrm{HW} 101$, had the highest solution concentration and a lower $\mathrm{pH}$ than the other samples. This led to a decrease in the $\mathrm{pH}$ of PVA- $\mathrm{H}_{3} \mathrm{BO}_{3}$, which was the solution with the lowest $\mathrm{pH}$ value (4.85), during gelation. The solution became more acidic and the degree of agglomeration decreased with respect to the other samples. Therefore, the ratio of $\mathrm{H}_{3} \mathrm{BO}_{3}$ increased, and the synthesis efficiency of PVBO is better than in the other samples. According to FTIR analysis, the $1287 \mathrm{~cm}^{-1}$ and $1080 \mathrm{~cm}^{-1}$ absorption peaks are ascribed to the $\mathrm{B}-\mathrm{O}-\mathrm{C}$ bonds, which are the main evidence for the PVBO formation. Peaks of $\mathrm{B}-\mathrm{O}-\mathrm{C}$ were obtained from the PHD101 sample, which was calcined under different conditions. The polymeric precursor was calcined to decompose the organic compounds. Borate ester bonds in the polymeric precursor were destroyed by heat treatment and yielded a reactant composed of the distributed $\mathrm{B}_{2} \mathrm{O}_{3}$ in the $\mathrm{C}$ matrix. The optimum value 
of $\mathrm{C} / \mathrm{B}_{2} \mathrm{O}_{3}, 3.34$, was achieved at $500{ }^{\circ} \mathrm{C}$ for $2 \mathrm{~h}$, with $\mathrm{B}_{2} \mathrm{O}_{3}$ being distributed at the nano-scale level in the carbon matrix. Finally, these samples were heat treated at $1400{ }^{\circ} \mathrm{C}$ for $5 \mathrm{~h}$. As a result, crystalline, irregular, and polyhedral $\mathrm{B}_{4} \mathrm{C}$ powder was synthesized from industrialgrade raw materials.

\section{REFERENCES}

1. Domnich V., Reynaud S., Haber R.A., Chhowalla M. (2011): Boron carbide: structure, properties, and stability under stress. Journal of the American Ceramic Society, 94, 3605-3628. doi: 10.1111/j.1551-2916.2011.04865.x

2. Thevenot F. (1990): Boron carbide a comprehensive review. Journal of the European Ceramic Society, 6, 205-225. doi: 10.1016/0955-2219(90)90048-K

3. Cicek B., Karaahmet O. (2018). Bor karbür ve düşük sıcaklık bor karbür sentezleme yöntemleri. $1^{\text {st }}$ ed. Nobel Akademik Yayıncılık.

4. Suri A.K., Subramanian C., Sonber J.K., Murthy T.S.R.Ch, (2010): Synthesis and consolidation of boron carbide: a review. International Materials Reviews, 1, 4-40. doi: 10.1179/ 095066009X12506721665211

5. Telle R., Sigl L.S., Takagi K. (2000). Boride-based hard materials, in: Riedel R. (Ed): Handbook of Ceramic Hard Materials. $1^{\text {st }}$ ed, pp.802-945. Wiley.

6. Werheit H. (2016): Boron carbide: consistency of components, lattice parameters, fine structure and chemical composition makes the complex structure reasonable. Solid State Sciences, 60, 45-54. doi: 10.1016/j.solidstatesciences. 2016.08.006

7. Ulrich S., Ehrhardt H., Schwan J., Samlenski R., Brenn R. (1998): Subplantation effect in magnetron sputtered superhard boron carbide thin films. Diamond and Related Materials, 7, 835-838. doi: 10.1016/S0925-9635(97)00306-3

8. Gogotsi G.A., Groushevsky Ya.L., Dashevskaya O.B., Gogotsi Yu.G., Lavrenko V.A. (1986): Complex investigation of hot-pressed boron carbide. Journal of the Less Common Metals, 117, 225-230. doi: 10.1016/0022-5088 (86) 90037-8

9. Hou X., Chou K.-C. (2013): Quantitative investigation of oxidation behavior of boron carbide powder in air. Journal of Alloys and Compounds, 573, 182-186. doi: 10.1016/j. jallcom.2013.04.012

10. Lee H., Speyer R.F. (2002): Hardness and fracture toughness of pressureless-sintered boron carbide $\left(\mathrm{B}_{4} \mathrm{C}\right)$. Journal of the American Ceramic Society, 85, 1291-1293. doi: 10.1111/j.1151-2916.2002.tb00260.x

11. Zhang Z., Du X., Wang J., Wang W., Wang Y., Fu Z. (2014): Synthesis and structural evolution of $\mathrm{B}_{4} \mathrm{C}-\mathrm{SiC}$ nanocomposite powders by mechanochemical processing and subsequent heat treatment. Powder Technology, 254, 131-136. doi: 10.1016/j.powtec.2013.12.055

12. Kalandadze G.I., Shalamberidze S.O., Peikrishvili A.B. (2000): Sintering of boron and boron carbide. Journal of Solid State Chemistry, 154, 194-198. doi: 10.1006/jssc. 2000.8835

13. Moshtaghioun B.M., Cumbrera-Hernández F.L., GómezGarcía D., Bernardi-Martín S.de, Domínguez-Rodríguez A., Monshi A., Abbasi M.H. (2013): Effect of spark plasma sintering parameters on microstructure and room-tem- perature hardness and toughness of fine-grained boron carbide $\left(\mathrm{B}_{4} \mathrm{C}\right)$. Journal of the European Ceramic Society, 33, 361-369. doi: 10.1016/j.jeurceramsoc.2012.08.028

14. Angers R., Beauvy M. (1983): Hot-pressing of boron carbide. Ceramics International, 10, 49-55. doi: 10.1016/ 0272-8842(84)90025-7

15. Alizadeh A., Taheri-Nassaj E., Ehsani N. (2004): Synthesis of boron carbide powder by a carbothermic reduction method. Journal of the European Ceramic Society, 24, 3227-3234. doi: 10.1016/j.jeurceramsoc.2003.11.012

16. Mohantya R.M., Balasubramanian K., Seshadri S.K. (2007): Multiphase formation of boron carbide in $\mathrm{B}_{2} \mathrm{O}_{3}-\mathrm{Mg}-\mathrm{C}$ based micropyretic process. Journal of Alloys and Compounds, 441, 85-93. doi: 10.1016/j.jallcom.2006.09.069

17. Deng F., Xie H.-Y., Wang L. (2006): Synthesis of submicron $\mathrm{B}_{4} \mathrm{C}$ by mechanochemical method. Materials Letters, 60 , 1771-1773. doi: 10.1016/j.matlet.2005.12.016

18. Jansson U., Carlsson J.-O., Stridh B., Söderberg S., Olsson M. (1989): Chemical vapour deposition of boron carbides I: phase and chemical composition, Thin Solid Films, 172, 81-93. doi: 10.1016/0040-6090(89)90120-X

19. Ramos A.S., Taguchi S.P., Ramos E.C.T., Arantes V.L., Ribeiro S. (2006): High-energy ball milling of powder B-C mixtures. Materials Science and Engineering A, 422, 184188. doi: 10.1016/j.msea.2006.01.096

20. Heian E.M., Khalsa S.K., Lee J.W., Munir Z.A. (2004): Synthesis of dense, high-defect-concentration $\mathrm{B}_{4} \mathrm{C}$ through mechanical activation and field-assisted combustion. Journal of the American Ceramic Society, 87, 779-783. doi: 10.1111/j.1551-2916.2004.00779.x

21. Shi L., Gu Y., Chen L., Qian Y., Yang Z., Ma J. (2003): A low temperature synthesis of crystalline $\mathrm{B}_{4} \mathrm{C}$ ultrafine powders. Solid State Communications, 128, 5-7. doi: 10.1016/S0038-1098(03)00627-6

22. Mondal S., Banthia A.K. (2005): Low-temperature synthetic route for boron carbide. Journal of the European Ceramic Society, 25, 287-291. doi: 10.1016/j.jeurceramsoc. 2004.08.011

23. Watts J.L., Talbot P.C., Alarco J.A., Mackinnon I.D.R. (2017): Morphology control in high yield boron carbide. Ceramics International, 43, 2650-2657. doi: 10.1016/j. ceramint.2016.11.076

24. Weimer A.W., Moore W.G., Roach R.P., Hitt J.E., Dixit R.S., Pratsinis S.E. (1992): Kinetics of carbothermal reduction synthesis of boron carbide. Journal of the American Ceramic Society, 75, 2509-2514. doi: 10.1111/j.1151-2916. 1992.tb05604.x

25. Foroughi P., Cheng Z. (2016): Understanding the morphological variation in the formation of $\mathrm{B}_{4} \mathrm{C}$ via carbothermal reduction reaction. Ceramics International, 42, 15189-15198. doi: 10.1016/j.ceramint.2016.06.126

26. Rafi-ud-din, Zahid G.H., Asghar Z., Maqbool M., Ahmad E., Azhar T., Subhani T., Shahzad M. (2014): Ethylene glycol assisted low-temperature synthesis of boron carbide powder from borate citrate precursors. Journal of Asian Ceramic Societies, 2, 268-274. doi: 10.1016/j.jascer.2014.05.011

27. Yanase I., Ogawara R., Kobayashi H. (2009): Synthesis of boron carbide powder from polyvinyl borate precursor. Materials Letters, 63, 91-93. doi: 10.1016/j.matlet.2008. 09.012

28. Kakiage M., Tahara N., Watanabe R., Yanase I., Kobayashi H. (2013): Microstructure in precursor formed by controlling composition of condensed boric acid-poly(vinyl 
alcohol) product for low-temperature synthesis of boron carbide powder. Journal of the Ceramic Society of Japan, 121, 40-44. doi: 10.2109/jcersj2.121.40

29. Barros P.M., Yoshida I.V.P., Schiavon M.A. (2006): Boroncontaining poly(vinyl alcohol) as a ceramic precursor. Journal of Non-Crystalline Solids, 352, 3444-3450. doi: 10.1016/j.jnoncrysol.2006.02.108

30. Sinha A., Mahata T., Sharma B.P. (2002): Carbothermal route for preparation of boron carbide powder from boric acid-citric acid gel precursor. Journal of Nuclear Materials, 301, 165-169. doi: 10.1016/S0022-3115(02)00704-3

31. Kakiage M., Tahara N., Yanase I., Kobayashi H. (2011): Low-temperature synthesis of boron carbide powder from condensed boric acid-glycerin product. Materials Letters, 65, 1839-1841. doi: 10.1016/j.matlet.2011.03.046

32. Kakiage M. (2018): Low-temperature synthesis of boride powders by controlling microstructure in precursor using organic compounds. Journal of the Ceramic Society of Japan, 126, 602-608. doi: 10.2109/jcersj2.18093

33. Pender M.J., Forsthoefel K.M., Sneddon L.G. (2003): Molecular and polymeric precursors to boron carbide nanofibers, nanocylinders, and nanoporous ceramics. Pure and Applied Chemistry, 75, 1287-1294. doi: 10.1351/pac 200375091287

34. Tahara N., Kakiage M., Yanase I., Kobayashi H. (2013): Effect of addition of tartaric acid on synthesis of boron carbide powder from condensed boric acid-glycerin product. Journal of Alloys and Compounds, 573, 58-64. doi: 10.1016/j.jallcom.2013.03.255

35. Chen X.W., Dong S.M., Kan Y.M., Zhou H.J., Hu J.B., Ding Y.S. (2016): Effect of glycerine addition on the synthesis of boron carbide from condensed boric acid-polyvinyl alcohol precursor. RSC Advances, 6, 9338-9343. doi: 10.1039/C5RA23303H

36. Kakiage M., Tominaga Y., Yanase I., Kobayashi H. (2012): Synthesis of boron carbide powder in relation to composition and structural homogeneity of precursor using condensed boric acid-polyol product. Powder Technology, 221, 257-263. doi: 10.1016/j.powtec.2012.01.010

37. Shawgi N., Li S.X., Wang S., Wang Z., Nie Y.N. (2017): Synthesis of nano particles and fiber-like shape boron carbide powder from ploy(vinyl alcohol) and boric acid. Journal of Sol-Gel Science and Technology, 82, 450-457. doi: 10.1007/s10971-017-4320-4

38. Kakiage M., Tahara N., Yanagidani S., Yanase I., Kobayashi H. (2011): Effect of boron oxide/carbon arrangement of precursor derived from condensed polymer-boric acid product on low-temperature synthesis of boron carbide powder, Journal of the Ceramic Society of Japan, 119, 422425. doi: $10.2109 /$ jcersj2.119.422

39. Najafi A., Golestani-Fard F., Rezaie H.R., Ehsani N. (2011): Effect of APC addition on precursors properties during synthesis of $\mathrm{B}_{4} \mathrm{C}$ nano powder by a sol-gel process. Journal of Alloys and Compounds, 509, 9164-9170. doi: 10.1016/j. jallcom.2011.06.103

40. Su W.-F. (2013). Principles of polymer design and synthesis. $1^{\text {st }}$ ed. Springer.

41. Tang X., Alavi S. (2011): Recent advances in starch, polyvinyl alcohol based polymer blends, nanocomposites and their biodegradability. Carbohydrate Polymers, 85, 7-16. doi: 10.1016/j.carbpol.2011.01.030

42. Finch C.A. (Ed.) (1992). Polyvinyl alcohol-developments. $2^{\text {nd }}$ ed., John Wiley $\&$ Sons.

43. Chan L.W., Hao J.S., Heng P.W.S. (1999): Evaluation of permeability and mechanical properties of composite polyvinyl alcohol films. Chemical and Pharmaceutical Bulletin, 47, 1412-1416. doi: 10.1248/cpb.47.1412

44. NPCS Board of Consultants\&Engineers (2009). The complete book on water soluble polymers. $1^{\text {st }}$ ed. Asia Pacific Business Press.

45. Balcı S., Sezgi N.A., Eren E. (2012): Boron oxide production kinetics using boric acid as raw material. Industrial \& Engineering Chemistry Research, 51, 11091-11096. doi: 10.1021/ie300685x

46. Yunlu K. (2016). Bor bilesikleri, sentez yontemleri, ozellikleri, uygulamaları. $1^{\text {st }}$ ed. Boren Ulusal Bor Araştırma Enstitusu.

47. Dias L.A.L., Alves W.A. (2019): Spectroscopic and conductometric behavior of boric acid in water and in an aprotic polar solvent. Journal of Molecular Liquids, 289, 111152 1-5. doi: 10.1016/j.molliq.2019.111152

48. Yoon D.Y., Kim J.-C. (2016): Hydrophobically modified poly(vinyl alcohol) and boric acid-containing monoolein cubic phase as a glucose-responsive vehicle. Colloids and Surfaces A: Physicochemical and Engineering Aspects, 506, 678-685. doi: 10.1016/j.colsurfa.2016.07.045

49. Fink J. (2015). Water-based chemicals and technology for drilling, completion, and workover fluids. $1^{\text {st }} \mathrm{ed}$. Gulf Professional Publishing.

50. Woo J.Y., Shin E.J., Lee Y.H. (2010): Effect of boric acid treatment on the crystallinity and drawbility of poly(vinyl alcohol)-1odinecomplexfilms.PolymerBulletin, 65, 169-180. doi: 10.1007/s00289-010-0279-9

51. Kakiage M., Tahara N., Tominaga Y., Yanagidani S., Yanase I., Kobayashi H. (2013): Effect of molecular structure of polyols with different molecular characteristics on synthesis of boron carbide powder. Key Engineering Materials, 534, 61-65. doi: 10.4028/www.scientific.net/KEM.534.61

52. Li X., Lei M., Gao S., Yan S., Wang X., Xing P. (2019): Effect of initial compositions on boron carbide synthesis and corresponding growth mechanism. Advances in Applied Ceramics Structural, Functional and Bioceramics, 118, 442-450. doi: 10.1080/17436753.2019.1664792 